\title{
The health of nine Royal Naval Arctic crews, 1848 to 1854: implications for the lost Franklin Expedition
}

\section{Keith Millar}

College of Medical, Veterinary and Life Sciences, University of Glasgow Institute of Mental Health, Gartnavel Royal Hospital, Great Western Road, Glasgow G12 0XH

(keith.millar@glasgow.ac.uk)

\section{Adrian W. Bowman}

School of Mathematics and Statistics, College of Science and Engineering, University of Glasgow, University Gardens, Glasgow G12 8QQ

\section{William Battersby}

College of Science and Engineering, University of Glasgow, University Gardens, Glasgow G12 8QQ

\section{Richard R. Welbury}

College of Medical, Veterinary and Life Sciences, University of Glasgow Dental Hospital and School, Sauchiehall Street, Glasgow G2 3JZ, and Royal College of Physicians and Surgeons of Glasgow, St. Vincent Street, Glasgow G2 5RJ

Received November 2015; revised version received January 2016; first published online 6 April 2016

ABSTRACT. Medical factors including tuberculosis, scurvy, lead poisoning and botulism have been proposed to explain the high death rate prior to desertion of the ships on Sir John Franklin's expedition of 1845-1848 but their role remains unclear because the surgeons' Sick books which recorded illness on board have eluded discovery. In their absence, this study examines the Sick books of Royal Naval search squadrons sent in search of Franklin, and which encountered similar conditions to his ships, to consider whether their morbidity and mortality might reflect that of the missing expedition. The Sick books of HMS Assistance, Enterprise, Intrepid, Investigator, Pioneer and Resolute yielded 1,480 cases that were coded for statistical analysis. On the basis of the squadrons' patterns of illness it was concluded that Franklin's crews would have suffered common respiratory and gastro-intestinal disorders, injuries and exposure and that deaths might have occurred from respiratory, cardiovascular and tubercular conditions. Scurvy occurred commonly and it was shown that the method of preparing 'antiscorbutic' lemon juice for the search squadrons and Franklin's ships would have reduced its capacity to prevent the disease but there were no grounds to conclude that scurvy was significant at the time of deserting the ships. There was no clear evidence of lead poisoning despite the relatively high level of lead exposure that was inevitable on ships at that time. There was no significant difference between the deaths of non-officer ranks on Franklin's ships and several of the search ships. The greater number of deaths of Franklin's officers was proposed to be more probably a result of non-medical factors such as accidents and injuries sustained while hunting and during exploration.

\section{Note on references}

References to Admiralty files currently held in the National Archives, Kew in London and which have no author are indicated in the text for example ADM38/7579. All are listed alphabetically under ADM in the list of references.

\section{Introduction}

For it is only with probabilities that we have to deal. Sir Edward Parry, 6 February 1850

Parry's statement to the Secretary of the Admiralty summed up the problem that faced the squadrons sent to the Arctic to search for Sir John Franklin and his 128 officers and men. The whereabouts of the missing expedition were quite unknown and might only be determined by various probabilities. For example, that Franklin had followed his sailing orders, or that the pack ice had allowed him to go one way rather than another. Such guesswork was informed by the experiences of previous Arctic expeditions.

The expedition's fatal end was eventually confirmed and the evidence of a high death rate through 1847 to 1848 has led to theories that health-related factors may have played a role. The present study attempts to gain insight into the state of health of Franklin's crews at the time of deserting their ships by reviewing the surgeons' Sick books of six of the most significant ships involved in the search. Evidence of tuberculosis, scurvy, lead poisoning or botulism in the search crews would be material because those conditions have been proposed to have contributed to the demise of the expedition. The near total absence of documentary evidence from the expedition itself means that, like Parry, one can only deal with the 'probabilities' that certain patterns of morbidity and mortality may have occurred, based upon those suffered by the search squadrons and inferred from the remains of the expedition members, 
and the circumstances known to have affected Franklin's ships.

\section{Brief history of the expedition}

The chronology of the Franklin expedition has been described in great detail by many authors (Brandt 2011; Cyriax 1939; Lambert 2009; Markham 1921; Owen 1978; Savours 1999) so that a brief summary will suffice here. On 19 May 1845 a Royal Naval expedition under the command of Captain Sir John Franklin departed from England aboard HMS Erebus and HMS Terror with the mission to gather scientific data and establish a northwest passage between the Atlantic and Pacific Oceans. The expedition had its last communication with Europeans in Baffin Bay in late July 1845.

The expedition entered winter quarters for 1845-1846 at Beechey Island where three men died. The ships then became terminally beset in Victoria Strait in September 1846 , some $19 \mathrm{~km}$ from the northwest coast of King William Island where the sole informative record from the expedition was recovered at Victory Point. The first portion of the record, which was written in May 1847, indicated satisfactory progress and ended positively with the statement: 'All well'. However, an addendum written eleven months later described a serious reversal of fortune: the ships had just been 'deserted' and the total deaths by then were nine officers and fifteen men, including Franklin who had died in June 1847. (As the specific term 'deserted' was written in the record by Captain Fitzjames of Erebus, its use is continued here). The intention was to proceed south to Back's Fish River in what is now Canada, leading most historians to assume that the 105 survivors intended to make for Hudson Bay Company outposts and safety.

The discovery of skeletal remains within only $80 \mathrm{~km}$ of Victory Point was interpreted as evidence that the crew had succumbed quickly to scurvy and starvation, and that the majority had died by the winter of 1848 . However, on 2 September 2014 a research team from Parks Canada discovered the wreck of HMS Erebus in Queen Maud Gulf many kilometres south of the last recorded position of the ships (Harris 2014). This discovery, combined with Inuit testimony, may support Woodman's (1991, 1995) revision of the traditional chronology which suggests that at least one ship was re-manned and that an unknown number of men may have survived until 1850 or 1851 .

\section{Evidence for morbidity and mortality, and the problem of the missing Sick books}

The permafrost-preserved corpses of the three men who died at Beechey Island during the first winter have shown evidence of mycobacterium tuberculosis and relatively high levels of lead in bone and soft tissue when compared to the present-day UK population (Amy and others 1986; Beattie and Geiger 1987; Kowal and others 1989; Notman and others 1987). The statement 'All well' made in the Victory Point record two years after departure in May 1847 would imply, if literally correct, that no unusual situation obtained at that time. The record does not describe what caused the further 21 deaths prior to desertion of the ships. The skeletal remains on King William Island vary widely in lead content and show uncertain evidence of scurvy. These findings are considered in detail below.

The mortality during the last winter would probably be explained if the Sick books kept by the expedition's surgeons had been recovered, but these, as with all the formal records of the expedition, have eluded discovery (Cyriax 1969). However, some insight to conditions aboard Franklin's ships may be gained from the Sick books of six other Royal Navy ships that searched for the expedition between 1848 and 1854. HM Ships Assistance, Enterprise, Intrepid, Investigator, Pioneer and Resolute were similarly equipped and provisioned, and encountered similar conditions to Franklin's ships. The Sick book of Investigator may provide specific insight because its disappearance provoked fears that the crew had 'become second Franklins' (Illustrated London News 1852) and, had they not been rescued, they would probably have met the same fate as Franklin's men.

\section{The Sick books and other sources}

The Sick books and other journals of many Royal Naval surgeons from 1793 to 1880 are held in the Admiralty Records at the National Archives, London, and have been transcribed as an on-line resource entitled 'Surgeons at sea' (www.nationalarchives.gov.uk). This valuable resource provides written details of individual cases but is not in a format to permit the statistical analysis required in this study. It was therefore necessary for the present authors to consult the original Sick books of the six ships of interest and to recode completely their daily records in order to compile a database to allow the quantitative analysis described. Other sources include the narratives of Investigator's surgeon Alexander Armstrong (1857), Resolute's master George McDougall (1857), the edited memoir of Richard Collinson of Enterprise (1889) and Barr (1992; 2007).

The Sick books have a standard format, recording the daily cases and their diagnoses, the time spent 'sick' and the three possible outcomes, namely discharged 'to duty', sent 'to hospital / invalid' (options when in port or near another home-bound vessel) and 'died'. Surgeons compiled an annual 'Nosological synopsis' of the cases according to formal categories of disease and a narrative of factors which had influenced the crew's health. Differences between surgeons in clinical judgment which may have introduced variability to the data were limited by an Admiralty regulation of 1824 which ensured some uniformity in training by requiring that a surgeon should hold a licence from the Royal College of Physicians and Surgeons of Glasgow or one of the Royal Colleges of Surgeons of Dublin, Edinburgh or London (Lloyd and Coulter 1963: 24). 
Table 1. The surgeon's Sick books held in the Admiralty Records of the National Archives, London, for the Royal Naval expeditions sent in search of the missing Franklin expedition during the period 1848 to $1854 .{ }^{1} \mathrm{ADM}=$ the catalogue reference within the Admiralty Records. ${ }^{2}$ For reasons described in the text, the data from Enterprise have a cut-point of 30 September 1854.

\begin{tabular}{|c|c|c|}
\hline Expedition dates and commander & HM Ships & Sick book $\mathrm{ADM}^{1}{ }^{\text {reference }}$ and dates covered \\
\hline $\begin{array}{l}\text { 1848-1849 } \\
\text { James Clark Ross }\end{array}$ & $\begin{array}{l}\text { Enterprise } \\
\text { Investigator }\end{array}$ & $\begin{array}{l}\text { ADM 101/99/4; } 5 \text { Feb } 1848 \text { to } 20 \text { Nov } 1849 \\
\text { Not found in Admiralty Records }\end{array}$ \\
\hline $\begin{array}{l}1849-1853 / 55 \\
\text { Richard Collinson } \\
\text { (via Behring Straits) }\end{array}$ & $\begin{array}{l}\text { Enterprise } \\
\text { Investigator }\end{array}$ & $\begin{array}{l}\text { ADM 101/99/5; } 14 \text { Dec } 1849 \text { to } 24 \text { May } 1855^{2} \\
\text { ADM 101/250; } 1 \text { Jan } 1850 \text { to } 3 \text { Jun } 1853\end{array}$ \\
\hline $\begin{array}{l}1850-1851 \\
\text { Horatio Austin } \\
\text { (via Lancaster Sound) }\end{array}$ & $\begin{array}{l}\text { Assistance } \\
\text { Intrepid } \\
\text { Pioneer } \\
\text { Resolute }\end{array}$ & $\begin{array}{l}\text { Not found in Admiralty Records } \\
\text { ADM } 101 / 105 / 1 ; 21 \text { Mar } 1850 \text { to } 9 \text { Oct } 1851 \\
\text { ADM } 101 / 113 / 1 \mathrm{~A} ; 25 \text { Feb } 1850 \text { to } 9 \text { Oct } 1851 \\
\text { ADM } 101 / 117 / 3 ; 28 \text { Jan } 1850 \text { to } 9 \text { Oct } 1851\end{array}$ \\
\hline $\begin{array}{l}\text { 1852-1854 } \\
\text { Edward Belcher }\end{array}$ & $\begin{array}{l}\text { Assistance } \\
\text { Intrepid } \\
\text { Pioneer } \\
\text { Resolute }\end{array}$ & $\begin{array}{l}\text { ADM } 101 / 87 / 8 ; 16 \text { Feb } 1852 \text { to } 15 \text { May } 1854 \\
\text { ADM } 101 / 105 / 1 ; 25 \text { Feb } 1852 \text { to } 15 \text { May } 1854 \\
\text { ADM } 101 / 113 / 1 B ; 21 \text { Apr } 1852 \text { to } 1 \text { Oct } 1853 \\
\text { Not found in Admiralty Records }\end{array}$ \\
\hline
\end{tabular}

The entire daily records of the ships shown in Table 1 were coded for entry into a database (SPSS V.22). The six ships each completed two missions so that a total of twelve crews were involved but the loss of three Sick books means that the data for only nine crews are available here. The consulting individual's name, age, rank, diagnosis, number of days spent sick and outcome were recorded, along with the date of the initial consultation which allowed analysis of the time spent on the voyage before specific symptoms appeared, such information being important in conditions such as scurvy. An individual might suffer the same condition on several occasions, or might suffer several different conditions, and, as each was recorded as a new case, the total number of cases exceeds the total complements of the ships. The resultant database consists of 1,365 cases.

\section{Limitations of the present study}

As will be seen, the Sick books were found to have significant omissions that make it impossible to determine the true incidence of serious conditions such as scurvy. Tubercular conditions probably also went undetected. Whilst these failings do not necessarily invalidate the proposal that the overall patterns of morbidity and mortality might provide insight to events aboard Franklin's ships, they do preclude the estimation of any quantitative probabilities that the conditions occurred. The term 'probabilities' might then be construed more loosely as 'possibilities'. When Parry conceded that the search for Franklin must rely upon certain 'probabilities' as to the expedition's whereabouts, he had no quantitative probabilities in mind, and the same limitation must apply here.

The search ships provided insight to factors such as inadequate antiscorbutic measures and variable success in hunting that might have affected the Franklin expedition. However, only the circumstances of Collinson's Enterprise and McClure's Investigator approximated to those of Franklin's ships in terms of the length of time spent in the Arctic, and only Investigator spent a similar time beset. Investigator's particular circumstances, for example, starvation as a consequence of the early loss of provisions, may have had no parallel in the Franklin expedition so that the ultimate dire state of Investigator's crew might not reflect that of Franklin's men when deserting the ships.

The diagnoses listed here are those made by the surgeons on the basis of contemporary medical knowledge. However, Guly $(2012,2013)$ has shown the misdiagnosis of illnesses in Antarctic expeditions due to the limitations of knowledge at the time. There would seem considerable scope for a more detailed examination of these data to determine, for example, the extent to which cardiovascular signs and symptoms were mistaken for those of scurvy. Finally, these data reflect the effects upon health of the specific conditions experienced by the Arctic discovery ships and might be evaluated in the wider context of the Royal Navy's global fleet. Clearly the health problems that arose in the Arctic environment differed from the tropical diseases that caused great mortality in other waters and it would be interesting to establish whether, despite the undoubted rigours of Arctic missions, those crews enjoyed overall better health. The present authors are not aware of any systematic analysis to conduct such a comparison but the Sick books held in the National Archives contain all the necessary data to do so.

\section{Results}

General patterns of morbidity and mortality

Table 2 shows the principal conditions recorded in the Sick books according to formal disease categories of the time. However, it must be recognised that diagnostic criteria change with time and that twenty-first-century medicine might classify some of the diseases differently. There is a total of 1,480 cases of which 1,365 can be linked to a named individual in the database. 
Table 2. Morbidity and mortality amongst crews of six Royal Naval ships during four searches for the Franklin expedition. Figures show number of cases for each condition; deaths are in parentheses. \# denotes cases where pulmonary tuberculosis was also evident at post mortem. \$ denotes a crewman of HMS Investigator who died of pulmonary tuberculosis in 1853 after transfer to HMS Resolute; his death was not recorded in the Investigator's Sick book and the Sick book for the Resolute is lost.

- denotes a death from scurvy that was not recorded in the Sick book of HMS Pioneer (see text).

\begin{tabular}{|c|c|c|c|c|c|c|c|c|c|c|}
\hline $\begin{array}{l}\text { HM Ship and } \\
\text { period of Sick book }\end{array}$ & $\begin{array}{l}\text { Enterprise } \\
1848-1849\end{array}$ & $\begin{array}{l}\text { Enterprise } \\
1849-1854\end{array}$ & $\begin{array}{l}\text { Investigator } \\
1850-1853\end{array}$ & $\begin{array}{l}\text { Resolute } \\
1850-1851\end{array}$ & $\begin{array}{l}\text { Pioneer } \\
1850-1851\end{array}$ & $\begin{array}{l}\text { Intrepid } \\
1850-51\end{array}$ & $\begin{array}{l}\text { Assistance } \\
1852-54\end{array}$ & $\begin{array}{l}\text { Pioneer } \\
1852-1853\end{array}$ & $\begin{array}{l}\text { Intrepid } \\
1852-1854\end{array}$ & All \\
\hline \multicolumn{11}{|l|}{ Condition } \\
\hline \multicolumn{11}{|l|}{ Fever/infection } \\
\hline various & 18 & 9 & 36 & $5(1)$ & 5 & 3 & 7 & 6 & 3 & $92(1)$ \\
\hline \multicolumn{11}{|l|}{ Central nervous system } \\
\hline headache/epilepsy & 2 & 0 & 2 & 1 & 1 & 0 & 1 & 4 & 0 & 11 \\
\hline \multicolumn{11}{|l|}{ Respiratory } \\
\hline bronchitis & $1(1)$ & 3 & 3 & 1 & 0 & 1 & 2 & 1 & $3(1)$ & $15(2)$ \\
\hline catarrh & 11 & 42 & 3 & 18 & 6 & 2 & 14 & 5 & 17 & 118 \\
\hline pneumonia & 0 & 0 & 3 & 0 & 1 & 0 & $1(1) \#$ & 0 & 0 & $5(1)$ \\
\hline phthisis (tuberculosis) & $2(1)$ & 3 & $1(1) \$$ & 0 & 0 & 0 & 0 & 0 & 0 & $6(2)$ \\
\hline other & $10(1)$ & 3 & 4 & 0 & 1 & 0 & 3 & 0 & 7 (1)\# & $28(2)$ \\
\hline \multicolumn{11}{|l|}{ Cardiovascular } \\
\hline various & 0 & $3(2)$ & $4(1)$ & 0 & 0 & 0 & 1 & 0 & $2(1)$ & $10(4)$ \\
\hline \multicolumn{11}{|l|}{ Gastro-intestinal } \\
\hline colic & 1 & 10 & 2 & 2 & 1 & 2 & 1 & 1 & 2 & 22 \\
\hline constipation & 2 & 22 & 1 & 1 & 2 & 2 & 0 & 1 & 0 & 31 \\
\hline diarrhoea \& dysentery & 15 & 24 & 31 & 3 & 4 & 4 & 4 & 9 & 8 & 102 \\
\hline dyspepsia & 8 & 15 & 10 & 5 & 5 & 1 & 16 & 8 & 21 & 89 \\
\hline other & 1 & 1 & 4 & 1 & 0 & 0 & 3 & 1 & 0 & 11 \\
\hline \multicolumn{11}{|l|}{ Hepatic } \\
\hline various & 0 & 0 & $6(1)$ & 0 & 0 & 0 & 1 & 1 & $2(1) \#$ & $10(2)$ \\
\hline \multicolumn{11}{|l|}{ Genito-urinary } \\
\hline syphilis and gonorrhoea & 3 & 31 & 6 & 5 & 2 & 5 & 2 & 0 & 0 & 54 \\
\hline other & 4 & 1 & 3 & 2 & 2 & 0 & 1 & 1 & 1 & 15 \\
\hline \multicolumn{11}{|l|}{ Musculo-skeletal } \\
\hline ‘rheumatism’ & 10 & 18 & 34 & 9 & 2 & 5 & 11 & 3 & 15 & 107 \\
\hline Other & 6 & 1 & 4 & 0 & 0 & 1 & $7(1)$ & 0 & 0 & $19(1)$ \\
\hline \multicolumn{11}{|l|}{ Skin/gland/cellular } \\
\hline scurvy \& debility & 0 & $13(2)$ & $48(1)$ & 1 & 0 & 0 & 0 & 1(1)• & 5 & $68(4)$ \\
\hline frostbite \& cold & 15 & 26 & 12 & 1 & 4 & 0 & 1 & 1 & 2 & 62 \\
\hline Oedema & 3 & 0 & 0 & 0 & 0 & 0 & 7 & 0 & 0 & 10 \\
\hline scrofula (tubercular) & 0 & 0 & 2 & 1 & 0 & 0 & 1 & 0 & 0 & 4 \\
\hline Other & $19(1)$ & 71 & 21 & 13 & 3 & 4 & 6 & 1 & 12 & $150(1)$ \\
\hline \multicolumn{11}{|l|}{ Sensory } \\
\hline 'snow blindness' & 18 & 61 & 24 & 4 & 3 & 2 & 7 & 1 & 1 & 121 \\
\hline \multicolumn{11}{|l|}{ Injuries \& wounds } \\
\hline various & 38 & 122 & 67 & 15 & 8 & 22 & 18 & 6 & 12 & 308 \\
\hline \multicolumn{11}{|l|}{ Other conditions } \\
\hline various & 4 & $4(2)$ & 2 & 0 & 0 & 0 & 0 & 1 & 1 & $12(2)$ \\
\hline Total cases & $191(4)$ & $483(6)$ & $333(4)$ & $88(1)$ & 50 & 54 & $115(2)$ & $52(1)$ & $114(4)$ & $1480(22)$ \\
\hline
\end{tabular}


A further single fatal case of phthisis has been added to the column for HMS Investigator. The officer concerned was transferred from the Investigator to die aboard HMS Resolute (Armstrong 1853) but his death was not recorded in the Sick book of Investigator, and the Resolute's Sick book is lost. The further 114 cases shown for Intrepid (1852-1854) could only be derived from the Nosological synopsis because the Sick book no longer contains the surgeon's daily record of individual cases and therefore lacks full information about the individuals concerned.

Injuries, frostbite and rheumatic conditions resulting from sledging operations were most common and reflected the harsh environment. Gastro-intestinal conditions, fevers and infections were also common. The exceptional number of cases of sexually transmitted disease aboard Collinson's Enterprise reflects the crew's activities during a stopover in Honolulu and wintering in Hong Kong.

More than half of the 22 deaths were the result of respiratory and cardiovascular illness. Ten tubercular conditions accounted for two deaths. Scurvy was recorded in 68 men, four of whom died. The latter two conditions are material in the context of the Franklin expedition and are discussed in detail below. It will be shown that the incidence of both diseases was under-recorded in the Sick books.

Evidence that the data in Table 2 might reflect some medical conditions suffered by the Franklin expedition may be inferred from the contents of a small medicine chest that was discovered at Victory Point on King William Island (McClintock 1859). The chest was evidently not the Royal Navy's standard issue but may have been the personal possession of one of the surgeons (Cyriax 1947; Millar and others 2015). It contained medicines to treat the conditions commonly suffered by the squadrons shown in Table 2, including diarrhoea, digestive disorders, rheumatic complaints, bronchitis and syncope, and to provide analgesia and reduce fever. Cyriax (1947) assumed that the medicines had been used until the crews arrived on shore after deserting the ships in April 1848, and that the depletion of the contents might indicate the prevalence of certain conditions. However, both assumptions must be questioned because it is unknown when the chest was left at Victory Point and, as the chest was non-standard issue, whether the medicine bottles were full when taken on board at departure in May 1845. A cautious conclusion would be that the chest provides some validation that the search crews and Franklin's men suffered similar conditions but cannot reliably associate those ailments with the period around the time of deserting the ships. Another medicine chest was found by the Inuit in one of the expedition's later camps at Terror Bay (Woodman 1991: 158) and might imply that some medical care continued after desertion of the ships.

\section{Health as a function of rank}

The first section of Table 3 shows the number and proportion of men of each rank who suffered on one or more occasions from six principal health conditions. The total complement within each rank is derived from the Muster book of the ships in Table 1 for which Sick books were available but does not include HMS Intrepid (18521854) for reasons described earlier. The data for petty officers and able seamen have been combined for two reasons. First, during a mission some men were promoted and demoted between the two ranks so that their rank could not be uniquely defined for statistical analysis. Secondly, some surgeons did not distinguish between the two ranks in the Sick books so that all petty officers were classed as able seamen (for example Anderson 1855). By combining the two categories, all men who represented one or both ranks are reliably included.

The total numbers of cases for each condition shows that there were differences between the ranks in the number of times that a man might suffer a given condition. For example, 19 officers made a total of 27 consultations for injuries (1.4 per man), while 167 petty officers and able seamen made 396 consultations for the same complaint (2.4 per man). The small number of warrant officers $(\mathrm{N}=14)$ means that their data should be considered with very considerable caution because an increase of one man suffering any given complaint causes a much greater proportional increase than in other ranks. Warrant officers were significantly older than the other ranks $(\mathrm{p}<0.005)$ but it is unclear whether their age made them more vulnerable to illness or simply more disposed to consult.

Officers suffered proportionately fewest of the conditions in Table 3 while petty officers and able seamen tended to suffer the most, the contrast reflecting the socioeconomic gradient in health that continues today. The main involvement of petty officers and able seamen in physical labour and man-hauled sledging would explain their predominance of injuries.

Differences between ranks were examined with the Chi-Square test with correction of the $\alpha$ level for multiple comparisons. The ranks differed in injuries $(\mathrm{p}<0.001)$, respiratory disorders $(\mathrm{p}<0.025)$ and infections $(\mathrm{p}<0.05)$ where all had a lower occurrence in officers, but only the difference in injuries remained significant after correction. Scurvy had a lower occurrence amongst officers and marines but was not significant $(\mathrm{p}=0.10)$. There was no significant difference between the ranks in cardiovascular conditions which had a very low occurrence.

Cardiovascular conditions accounted for deaths amongst petty officers, able seamen and marines, and respiratory conditions amongst the latter two ranks and officers. The four deaths from scurvy were petty officers/able seamen. Two deaths were exceptional: one of Collinson's officers was murdered while ashore and another committed suicide. The surgeon wrote diplomatically of the latter that it was 'not necessary to relate the causes of this sad event' (Anderson 1855; narrative note of 19 June 1851) for it was alleged to be due to Collinson's vindictive treatment (Barr 2007: 83). Overall, $6 \%$ of officers died, in marked contrast to the $39 \%$ of 
Table 3. The number $(\mathrm{N})$ and proportion (Ppn) in each rank suffering on one or more occasions from six health conditions, and the total number of consultations for that condition (TNC). The causes of death, mean age and mean/median days sick as a function of rank (data for health conditions exclude HMS Intrepid for 1852-1854 because these were not assigned to ranks in ADM 101/105/1. The causes of death on Ross's Investigator were found in Gilpin (1850) and Lloyd and Coulter (1963) but the Muster Book (ADM 35/8387) does not link causes of death to the names or ranks of the deceased.

\begin{tabular}{|c|c|c|c|c|}
\hline $\begin{array}{l}\text { Rank and } \\
\text { number in } \\
\text { complement }\end{array}$ & $\begin{array}{l}\text { Officers } \\
72 \\
\text { N/ Ppn / TNC }\end{array}$ & $\begin{array}{l}\text { Warrant } \\
\text { Officers } \\
14 \\
\text { N/ Ppn / TNC }\end{array}$ & $\begin{array}{l}\text { Petty Officers } \\
\text { \& Able } \\
\text { Seamen } \\
273 \\
\text { N/Ppn / TNC }\end{array}$ & $\begin{array}{l}\text { Royal } \\
\text { Marines } \\
59 \\
\text { N/ Ppn / TNC }\end{array}$ \\
\hline \multicolumn{5}{|l|}{ Conditions } \\
\hline $\begin{array}{l}\text { Injuries } \\
\text { Gastro-intestinal } \\
\text { Respiratory } \\
\text { Scurvy } \\
\text { Infection } \\
\text { Cardiovascular }\end{array}$ & $\begin{array}{c}19 \text { / } 0.26 / 27 \\
17 / 0.24 / 25 \\
8 / 0.11 / 13 \\
4 / 0.06 / 4 \\
4 / 0.06 / 4 \\
1 / 0.01 / 1\end{array}$ & $\begin{array}{l}8 / 0.70 / 9 \\
6 / 0.35 / 14 \\
3 / 0.35 / 3 \\
2 / 0.15 / 2 \\
2 / 0.20 / 2 \\
0 / 0.00 / 0\end{array}$ & $\begin{array}{c}167 \text { / } 0.61 / 396 \\
99 / 0.36 / 150 \\
77 / 0.28 \text { / } 112 \\
37 / 0.14 \text { / } 52 \\
53 / 0.19 / 71 \\
6 / 0.02 \text { / } 6\end{array}$ & $\begin{array}{l}27 / 0.46 / 44 \\
21 / 0.36 / 24 \\
12 / 0.20 / 16 \\
3 / 0.05 / 5 \\
9 / 0.15 / 12 \\
1 / 0.02 / 1\end{array}$ \\
\hline Deaths* & $\begin{array}{l}\text { murder } \\
\text { suicide } \\
\text { respiratory }(\mathrm{N}=2)\end{array}$ & nil & $\begin{array}{l}\text { scurvy }(\mathrm{N}=4) \\
\text { infection }(\mathrm{N}=2) \\
\text { cardiovascular }(\mathrm{N}=2) \\
\text { respiratory }(\mathrm{N}=2) \\
\text { hepatic }\end{array}$ & $\begin{array}{l}\text { respiratory } \\
\text { cardiovascular }\end{array}$ \\
\hline Age: mean (SD) & $31.7(8.49)$ & $\begin{array}{l}38.0(8.56) \\
(p<0.005)\end{array}$ & $29.8(6.20)$ & $31.2(4.36)$ \\
\hline $\begin{array}{l}\text { Days sick } \\
\text { mean (SE) } \\
\text { median (IQR) }\end{array}$ & $\begin{array}{l}15.9(3.01) \\
6(12)\end{array}$ & $\begin{array}{l}10.3(4.41) \\
5(12)\end{array}$ & $\begin{array}{l}14.4(0.93) \\
6(11)\end{array}$ & $\begin{array}{l}20.4(2.49) \\
7(12)\end{array}$ \\
\hline $\begin{array}{l}\text { *Deaths } \\
\text { recorded on } \\
\text { Intrepid (4) and } \\
\text { Ross's } \\
\text { Investigator (3) }\end{array}$ & $\begin{array}{l}\text { Unassigned to } \\
\text { rank: } \\
\text { respiratory (2) } \\
\text { cardiovascular } \\
\text { (2), hepatic, } \\
\text { infection, scurvy }\end{array}$ & & & \\
\hline
\end{tabular}

officers on the Franklin Expedition who died within three years.

Four deaths due to respiratory $(\mathrm{N}=2)$, cardiovascular and hepatic conditions aboard Intrepid (1852-1854) and three deaths due to scurvy, infection and cardiovascular illness aboard Ross's Investigator are shown separately as it was not possible to link the deaths to particular ranks (only the Nosological synopsis for Intrepid is available while the Sick book of Investigator for 1848-1849 is lost). The Muster books of both ships (ADM 38/8387; ADM 38/8863) record the names and ranks of those who died but not the causes of death: however, none was an officer.

The number of 'Days sick' showed a positive skew for most conditions because of the longer time that a few men were under treatment (confirmed by the contrast between the mean and median values in Table 3). A square root transformation provided a better approximation to a Gaussian distribution prior to analysis that showed that the ranks did not differ significantly in the number of days spent sick. The greater mean number of days spent sick by Royal Marines is a consequence of two men being under treatment for 370 and 448 days for 'lumbago' and 'phthisis', respectively.

\section{Tuberculosis}

Pulmonary tuberculosis, 'phthisis', was a leading cause of death in men of 18 to 34 years of age in mid19th-century England (Woods 2000; Woods and Shelton 1997). This age range represents the majority of the men of the search ships and of Franklin's ships. Tubercular disease was suspected in able seaman John Hartnell and Marine William Braine of Franklin's expedition who died at Beechey Island (Notman and others 1987). In the search ships, phthisis was recorded in six men, two of whom died. 'Scrofula' (tuberculosis affecting the lymph glands) was diagnosed in four men. These relatively small numbers may reflect successful exclusion of men with symptoms of the disease at recruitment (Bradford 1851). However, non-symptomatic individuals might escape detection as illustrated by the death from pulmonary tuberculosis of Henry Matthias, the assistant surgeon of Ross's Enterprise, as would those who connived to hide their symptoms such as Marine William Cutbush on Belcher's Assistance (Lyall 1854). Post mortem examinations also discovered tuberculosis when it was not the primary cause of death. For example, two men who died from hepatitis and pleuritis on Intrepid (18521854) and Cutbush who died of pneumonia were shown 
also to have pulmonary tuberculosis (Lyall 1854; Scott 1854) although, clearly, the apparent primary pulmonary problems may have been connected to the tubercular condition. Two cases of haemoptysis (coughing of blood) would also be suggestive of the disease (Intrepid 18521854). Royal Naval surgeons were required to conduct a post mortem only after sudden or unexpected deaths (His Majesty's Stationery Office 1835), so it is possible that other tubercular conditions were not discovered. Moreover, post mortem examinations were conducted on board in less than ideal conditions and by men who were not necessarily experienced in pathology (acknowledged by Robertson 1855). Simple failures to record diagnosed cases also contributed to underestimating the occurrence of the disease: for example, in addition to the omission of a fatal case of phthisis in the Sick book of Investigator, the surgeon also omitted a case of phthisis incipiens from the Nosological summary. As the disease is under-recorded in these data it is impossible to attempt to estimate reliably the incidence of tuberculosis in the crews.

\section{Scurvy}

Table 2 shows that 68 cases of scurvy and associated debility accounted for four deaths in the search crews but it will be seen that the disease was greatly under-reported so that its true incidence is obscured. Given the supposed effects of scurvy upon the Franklin expedition, the condition is considered in detail below by first examining its occurrence in the individual ships of these squadrons. The evident failure to prevent scurvy will then be examined in light of the methods used to prepare lemon juice as an antiscorbutic prophylactic for these Arctic crews. The provisioning of Franklin's ships will then be considered, and the evidence for scurvy in the crews.

\section{James Clark Ross's expedition of 1848-1849}

HMS Enterprise and HMS Investigator were newly built for Ross's search. As an historical digression, it had been intended that Investigator be named Sir Edward Parry but the name was changed before the launch (Robb 1993; Scotts of Greenock 1848). The Sick book of Investigator has not survived but it is known that three deaths were due to scurvy, post-operative infection and pericarditis (Gilpin 1850; Lloyd and Coulter 1963: 112). The pattern of health aboard Enterprise shown in Table 2 may be representative of both ships.

Although Table 2 shows that the surgeon John Robertson (1849) did not record any cases of scurvy in the daily Sick book, he stated in his narrative that ' $[\mathrm{t}]$ here were few $[\ldots]$ who were not more or less affected by scurvy; and $[\ldots]$ had we remained out another winter, few if any would have returned'. The consequence of Robertson's unexplained omission of any quantitative data concerning this serious condition is greatly to underrepresent the incidence of the disease. If his statement that 'few' were not affected by scurvy is correct then, as Enterprise and Investigator had a total complement of 132 men, it would imply that the data in Table 2 fail to include many scores of cases. Robertson blamed poor provisions and ineffective 'antiscorbutic' lemon juice. His own severe case of scurvy showed no improvement even with massive daily doses of lemon juice that implies that it lacked any significant vitamin $\mathrm{C}$ (see further below). The problem was compounded by the total absence of game to supplement their diet.

\section{Horatio Austin's expedition of 1850-1851}

The expedition involved Assistance, Intrepid, Pioneer and Resolute. The Sick book for Assistance has not survived but its Muster book shows that no deaths occurred (ADM 38/7579). The expedition suffered only minor morbidity and one fatality on Resolute due to gangrene supervening from frostbite (Table 2). This good outcome may reflect the short mission which involved only one winter in the Arctic, and light work for there was no compulsory 'out-of-door working' under Austin (Admiralty Committee on Scurvy 1877: 98). The single case of scurvy on the Resolute was not a crew member but the cook from Sir John Ross's yacht Felix (Bradford 1851). The elderly Ross had accompanied the squadron to honour his promise to Franklin that he would come to his aid if needed.

\section{Sir Edward Belcher's expedition of 1852-1854}

Belcher returned to the Arctic with the ships of the Austin squadron and spent two winters. Whilst no cases of scurvy appear in the daily Sick book for Assistance (Table 2), the surgeon reported in his narrative that scurvy was frequently present in sledge parties but did not record the numbers involved. He did, however, record that one man was so severely disabled by the disease as to be unable to return to Assistance from the depot ship North Star (Lyall 1854). McDougall (1857: 245) also observed scurvy in Resolute's sledge parties and de Bray mentioned 'minor' cases of the disease on board (Barr 1992: 220) but the Sick book has not survived so that, again, the number is not known (de Bray's general observations of health on Resolute are found in Barr (1992)) An able seaman on Pioneer was diagnosed with scurvy and sent to Assistance for treatment but the outcome was not recorded in the Sick book of either ship: the present authors discovered the listing of his death in the Muster book (ADM 38/7580). Clearly, therefore, the incidence and outcome of scurvy are under-estimated in these data. Belcher was not recorded in the Sick book but stated in a memoir that he suffered scurvy in one of its 'Protean forms' (Belcher 1855, II: 104, 105): his self-described symptoms are not those of scurvy but are consistent with depression which would seem supported by McClintock's description of his state (see Williams 2010: 324).

As Belcher's judgment during the expedition has often been called in question (for example by Markham 1921), it might also be noted that, just as his 'Protean' symptoms were not those of scurvy, nor were they those of the syphilis that had led to the humiliation of the 
legal case brought by his wife for infecting her with the disease (Phillimore 1835). Had Belcher been suffering the mental, motor and sensory effects of the tertiary stage of the disease his incapacity would have been abundantly clear to all.

The poor health of the crew of Intrepid attracted comment (McDougall 1857: 365): four of the five cases of scurvy (one sixth of the crew) occurred after only one winter in the Arctic, and deaths were due to cardiac hypertrophy, bronchitis, pleuritis and hepatitis.

\section{Richard Collinson's expedition of 1850-1855}

With Collinson in overall command aboard Enterprise and Robert McClure commanding the Investigator, the ships were despatched to enter the western Arctic as consorts but, for reasons described by Barr (2007), they separated and met very different fates.

After an unsuccessful attempt to penetrate east of Point Barrow, Enterprise spent the winter of 1850 in Hong Kong, only entering the Arctic in summer 1851. As the last ten months of the mission involved the westerly return voyage when illnesses could not be directly attributed to conditions while in the Arctic, the data in Table 2 have a cut-point of 30 September 1854, Enterprise having left the ice in July 1854. The diagnosis of scurvy in one man only five weeks after departure from England suggests a failure in medical screening (he had been one of many who suffered scurvy on the preceding Ross expedition: Anderson 1855). It might also imply that his diet was deficient in vitamin $\mathrm{C}$ (see below) even at that early stage in the mission, or that he suffered a condition causing malabsorption of the vitamin. A further four cases of scurvy, one being fatal, occurred in 1852 after only one winter in the Arctic and despite daily 'antiscorbutic' lemon juice. There were thirteen recorded cases by September 1854, two being fatal, and the surgeon stated in his narrative that further milder cases occurred but did not record the number (Anderson 1855). Two deaths were due to cardiac conditions. The surgeon noted that the crew benefited in the early part of the mission from mild Arctic weather and light work, and from success in hunting to supplement their provisions. However, they suffered similar illnesses to the other ships and certainly did not escape scurvy so that Houston's (1990: 165) assertion that the crew did not suffer scurvy at all is clearly completely incorrect. Whilst Enterprise completed its mission in fair health, the fortunes of the Investigator were very different.

Investigator entered the Arctic in July 1850 and spent two winters beset before being abandoned (see Stein 2015). In autumn $1850,1,520 \mathrm{~kg}$ of prime beef were lost overboard while lightening the ship after running aground and $230 \mathrm{~kg}$ of preserved meats were found unfit for consumption (Armstrong 1857: 119, 264). These losses resulted in rations being reduced by one third in September 1851, although the full ration of lemon juice was maintained.
Table 4. State of health of the crew of HMS Investigator sent to HMS Resolute as determined by medical inspection (Armstrong and Domville 1853). ${ }^{1}$ The scorbutic symptoms were primarily oral involving lividity, bleeding and ulceration of the gums; ${ }^{2}$ intradermal haemorrhage; ${ }^{3}$ vomiting of blood; ${ }^{4}$ coughing of blood.

\begin{tabular}{|lr|}
\hline Crew of HMS Investigator & $\mathrm{N}$ \\
\hline State of health & 4 \\
\hline 'Good/fair health' & 13 \\
$\quad$ + scorbutic symptoms' & 1 \\
Scurvy of 'aggravated form' & \\
Scorbutic symptoms: & 5 \\
unspecified & 7 \\
livid/ulcerated gums \& petechiae ${ }^{2}$ & 12 \\
$\quad$ + oedema / dropsy & 9 \\
+ debility & 2 \\
$\quad$ + dysentery \& haematemesis & \\
$\quad$ + haemoptysis & 1 \\
$\quad$ + 'rheumatism' & 1 \\
+ tonsillitis & 1 \\
Tubercular tumour & 1 \\
Epilepsy 'now imbecile' & 1 \\
Pulmonary disease \& 'deranged' & 1 \\
Total & 59 \\
\hline
\end{tabular}

The first case of scurvy occurred in April 1852 and seven more by June, despite the full ration of lemon juice and some success in hunting (Osborn 1856: 237). In September, the rations were further reduced, including halving of the ration of lemon juice. Gastro-intestinal illness and scurvy predominated in the first five months of 1853 when '[f]ainting and syncope were constantly present on making the slightest exertion [...] and scurvy of an aggravated character seldom failed to supervene' (Armstrong 1857: 555). Chest pain and palpitations were also common on exertion (Armstrong 1853).

Fortunately, a rescue party arrived from HMS Resolute before McClure could implement his plan to send the weakest men from the ship to seek rescue: they would have had no hope of survival (Armstrong 1857: 543). The rescuers were appalled by the condition of the crew. Two died after reaching Resolute suffering scurvy, cardiac failure and oedema, and one with tuberculosis; one had died on Investigator only the day before rescue, possibly by suicide while suffering scurvy and dysentery. A medical inspection of the crew was demanded by Captain Kellett of Resolute and its outcome, summarised in Table 4, confirms their dire state (Armstrong and Domville 1853). Only four men were in good or fair health: the rest, including McClure, showed clear signs of scurvy and other serious illnesses. Given this stark evidence, it is unclear what led McCord (1972: 235) to assert that 'there was no scurvy present' on Investigator. Three of the crew were not formally examined but the surgeons recorded that ' $[\mathrm{t}]$ he lieutenant $[\ldots]$, the mate and assistant surgeon $[\ldots]$ were much debilitated $[\ldots]$ and the mate was also insane' (Armstrong and Domville 1853). 


\section{The preparation of lemon juice as an antiscorbutic}

It is evident that scurvy affected all the search ships that spent more than two winters in the Arctic, and two ships after only one winter, and that the occurrence of the disease was under-recorded. These squadrons and Franklin's ships were supplied with lemon juice to prevent scurvy so it is important to understand why, despite this measure, the disease occurred.

Scurvy arises from an inadequate dietary intake of vitamin $\mathrm{C}$ (ascorbic acid). The consequent impaired production of collagen results in fragility of the blood capillaries so that haemorrhage around the hair follicles and bleeding of the gums typically occurs within four to six months of the body pool of the vitamin being exhausted. Minor trauma to the lower limbs will provoke haemorrhage and fractures in the bone cortex (Fain 2005). Haemorrhage occurs in the joints and may also occur in the gastro-intestinal tract and pericardium (Pemberton 2006). Untreated, scurvy will be fatal. A daily intake of $10 \mathrm{mg}$ of vitamin $\mathrm{C}$ will prevent scurvy in largely sedentary men but $40-45 \mathrm{mg} /$ day is recommended (Truswell and Mann, 2012) to allow for factors such as strenuous activity that may increase the body's vitamin C requirement (Norris 1983), and smoking (May 2013). All of the present ships, and Franklin's ships, were abundantly supplied with tobacco (ADM 114/17, ADM 114/18 and ADM 114/21) in quantities which provided each man well in excess of the equivalent of smoking 20 cigarettes per day which reduces serum ascorbate by $40 \%$ (May 2013; Truswell and Mann 2012).

The introduction of lemon juice to prevent scurvy in Royal Naval crews has been critically reviewed in great detail by Baron (2009), Carpenter (1986), Crimmin (2013) and Vale (2008). Vitamin C is the critical antiscorbutic constituent of lemon juice but vitamins were unknown in the 19th century and the antiscorbutic effect was attributed, inter alia, to its citric acid content. Freshly-squeezed lemon juice has a typical vitamin C content of $45.6 \mathrm{mg} / 100 \mathrm{ml}$ (Artés-Hernández and others 2007 ) so that the Navy's daily 1 ounce/ $28.4 \mathrm{ml}$ dose for Arctic crews provided $12 \mathrm{mg}$ which, fortuitously, was just $2 \mathrm{mg}$ above the minimum $10 \mathrm{mg}$ requirement described above. However, vitamin $\mathrm{C}$ is vulnerable to heat, storage time and oxidation (Hughes 1975, 1990; Trusswell and Mann 2012). For example, almost $50 \%$ of the vitamin $\mathrm{C}$ content of fresh juice is lost after heating to $90^{\circ} \mathrm{C}$ for only 3 minutes (Vikram and others 2005: Fig. 3). Consequently, the early methods of boiling the juice in an attempt to concentrate or preserve its antiscorbutic properties led inevitably to the destruction of the vitamin C content (Hughes 1975: 342; Priston 1926: 7). Savours and Deacon's (1981) conclusion that the Navy's ration would not allow for loss of the vitamin content during preparation or storage, and therefore would not permit any margin to build up a reservoir of protection when men were subject to strenuous exercise (noted above in sledge parties from Assistance and Resolute), would seem fully supported by the evidence above.
The Royal Navy's Deptford Victualing Yard supplied the lemon juice to the ships in Table 2 and to the Franklin expedition. The methods of preparing and storing the juice are likely to have significantly reduced its vitamin C content (see Hughes 1990). Carpenter (1986: 197, 237, 240) has described how storing the juice in settling tanks for up to a month, and subsequently pumping it through copper piping, would cause aerobic breakdown of vitamin C. An Admiralty enquiry into the ineffectiveness of the juice supplied to Ross's 1848-1849 expedition blamed its storage conditions (Lloyd and Coulter 1963: 112). The practice of floating a thin stratum of olive oil on the surface of the juice in ship-board jars and kegs (Armstrong 1858:17) was recognition of the harmful effects of exposure to air in the container's headspace but would seem unlikely to ensure separation during agitation of the contents when transported or in rough seas and when eventually decanted for use.

That it was also common practice to boil the juice is confirmed in correspondence concerning the Belcher expedition which advised that the juice could not be supplied for departure because 'the Boilers cannot be got ready in time to boil the juice required'. It had been intended to boil all the juice (ADM 114/18, 26 February and 12 March 1852). Belcher agreed that $553 \mathrm{~kg}$ of boiled juice which had been returned from the preceding Austin expedition should supplement whatever could be prepared for him (ADM 114/18, 18 March 1852): the boiled juice was then more than two-years old. Other 'raw' juice was 'drawn off' (ADM 114/18, 10 March 1852), presumably from store, and 'fortified' by adding $10 \%$ brandy which had the benefit of reducing the freezing point of the mixture (Drummond and Lewis 1938: 814) but also the inevitable adverse consequence of reducing by $10 \%$ the vitamin $\mathrm{C}$ content by volume. Furthermore, the alcohol itself may have significantly reduced the vitamin $\mathrm{C}$ content because, in an early study, Bennett and Tarbert (1933) demonstrated a $41 \%$ reduction in the ascorbic acid content of fresh lemon juice only eight days after the addition of $10 \%$ alcohol as a preservative. Regrettably, this important study does not appear to have been replicated using modern assays. It was shown above that scurvy affected unknown numbers on Belcher's Assistance and Resolute, and one sixth of the crew of Intrepid.

For Collinson's expedition of 1850, the 'fresh' lemon juice was supplied from an external contractor's existing stock because it was discovered to be cheaper than having the lemons squeezed at Deptford (ADM 114/21, 24 December 1849). As it would have taken at least one month to squeeze the required quantity (ibid.), much of it must have been stored for at least that period of time and been exposed to oxidation because it was stored in sherry casks (ibid.) which are permeable to air (Nevares and del Alamo-Sanza 2015). The juice was then prepared in two ways to allow a simple experiment to determine which was the more effective antiscorbutic (ADM 114/21). One half of the lemon juice was boiled 
while the remainder was fortified with $10 \%$ brandy, the effects of both treatments being to reduce the vitamin $\mathrm{C}$ content for the reasons described above. Indeed, Lloyd and Coulter (1963: 113) concluded that boiling would have destroyed much of the vitamin $\mathrm{C}$ content.

The boiled and fortified juices were then twice subjected to 'the highest degree of Equatorial heat' (Armstrong 1858: 93) during the voyage via the east and west coasts of South America. In the Arctic, it froze solid in the holds (a common problem as described by Bradford 1851; Pickthorn 1851; Scott 1854) and was thawed by heating, thus further reducing the vitamin $\mathrm{C}$ content, before being 'mixed in separate tubs' (Armstrong 1858: 18) which further exposed it to oxidation. Armstrong's conclusion that both preparations were effective antiscorbutics would seem contradicted by the occurrence of the disease even when the full ration of lemon juice was provided.

Scurvy first appeared on both Enterprise and Investigator in spring 1852 which, given the delay in onset of symptoms described above, suggests that the diet was becoming deficient in the vitamin in late 1851. Whilst general rations on Investigator had been reduced that autumn, the full ration of lemon juice was maintained until September 1852. It appears that the juice lacked effectiveness after less than two years and that it was the reduction in food rations that was material in denying the men a critical source of the vitamin. This inference is supported by Armstrong's telling observation that scurvy appeared only after the ration of preserved potato had been reduced (Armstrong 1858: 112).

It is notable that the preparation of lemon juice for Collinson's Enterprise and McClure's Investigator differed from that for the Austin squadron that departed a few months later in 1850 . For unstated reasons, only one-sixth of the lemon juice for Austin's ships was to be boiled (ADM 114/17, 2 April 1850). A further 'hogshead of brandy' was ordered to fortify the remaining fivesixths. It was noted above that Austin's squadron enjoyed largely good health and that scurvy was absent. However, whether this good outcome was due to the lemon juice is confounded by the fact that it was a short mission involving only one winter in the Arctic and where the crews had light work and hunted for fresh meat. As described above, the boiled juice returned from Austin's expedition would be assigned, six months later, to Belcher.

\section{Other antiscorbutics}

The search squadrons supplemented their diet with other foods that contained vitamin C. Cress and mustard were supplied as seed and grown below decks (for example Lyall 1854; Belcher 1855, I: 342) and wild sorrel was gathered, providing vitamin C contents of $104 \mathrm{mg}, 36 \mathrm{mg}$ and 63mg/100g, respectively (Hughes 1990; MartínezSánchez and others 2008; Lee and Kader 2000). Vitamin $\mathrm{C}$ in canned foods would have been reduced by $75 \%$ by their methods of production (Bender 1981) but surgeons observed empirically that preserved potatoes retained antiscorbutic properties (Bradford 1851) when lemon juice was entirely ineffective (Robertson 1849). Boiled potatoes retain $10 \mathrm{mg} / 100 \mathrm{~g}$ of vitamin C (Truswell and Mann 2012). Fresh meat procured from hunting was much valued as an antiscorbutic but in fact contains relatively little vitamin $\mathrm{C}$ and even less after cooking (for example raw caribou flesh $1.4 \mathrm{mg} / 100 \mathrm{~g}$; cooked 0.9mg/100g: Geraci and Smith 1979). Similarly, even if fishing were successful, large quantities would have been required because the flesh of the Arctic char and cod contain only some 0.5 to $2.0 \mathrm{mg} / 100 \mathrm{~g}$ of vitamin $\mathrm{C}$ when raw and substantially less (although not determined) when cooked (Carpenter 1986: 232; Geraci and Smith 1979). The men probably derived more vitamin $\mathrm{C}$ when they ate offal. For example, the content in raw and boiled liver is 35 and $13.6 \mathrm{mg} / 100 \mathrm{~g}$, respectively (ibid.) Sir John Ross's advocacy of curry powder as a powerful antiscorbutic does not appear to have been adopted (ADM 114/19, 18 March 1850): presumably, a rational line had to be drawn somewhere.

One should note that Jones and Hughes (1976) have shown that cooking any of these foods in copper pans commonly used in ships' galleys would markedly reduce their vitamin $\mathrm{C}$ content because the metal acts as a catalyst in the aerobic breakdown of the vitamin. The effect would add to losses caused by heat itself during cooking or warm keeping (Truswell and Mann 2012: 238-240).

It is therefore doubtful that lemon juice alone could reliably protect these crews from scurvy. The supposed effectiveness of the juice was probably confounded with the highly variable contribution of vitamin $\mathrm{C}$ from hunting and other foods. It is material to consider whether the provisioning of Franklin's ships might have rendered its men vulnerable to scurvy.

\section{Scurvy and the Franklin crews}

\section{Provisioning HMS Erebus and HMS Terror}

The victualing correspondence for Erebus and Terror carries the instruction '[t]he lemon juice to be strengthened' (ADM 114/17, 10 January 1845). If 'strengthened' was a synonym for the 'fortified' juice supplied to Collinson, it implies the addition of $10 \%$ brandy which would have reduced by $10 \%$ the vitamin $\mathrm{C}$ content by volume, and by a further unknown amount due to the interaction with alcohol (Bennett and Tarbert 1933). It is not recorded whether all or part of the juice was also boiled although, as noted, it was common practice to do so. The juice was supplied in 5-gallon kegs with the instruction that they be watertight (ADM 114/17, 11 March 1845), which may have reduced their permeability to oxygen but not that of the cork bung (Lequin and others 2012).

If the juice supplied to Franklin's ships was subject to the same loss of vitamin $\mathrm{C}$ as in the search squadrons then, by the early winter of 1847 , dietary levels of the vitamin supplied by the juice alone would have been marginal. Without supplement from other sources, symptoms of scurvy might be expected to have 
appeared in early 1848. Their canned food would have provided little vitamin $\mathrm{C}$, with the possible exception of the 5343 pounds $/ 2428 \mathrm{~kg}$ of preserved potato (ADM 114/17, 29 March 1845), while the pickled vegetables and fruits would have been devoid of the vitamin (Hughes 1975). There is no record in the highly-detailed victualing list that mustard and cress seeds were supplied (ADM 114/17) and it is unknown whether sorrel was gathered.

The expedition intended to procure as much game as possible (Bell 1881) and a possible shooting station was identified on King William Island by Hobson during McClintock's (1859) search (Stenton 2014) but it is unknown whether hunting was successful. Hobson travelled the shoreline from Cape Felix to Cape Herschel and concluded that ' $[\mathrm{t}]$ here is not the slightest chance of a party subsisting by hunting on this shore, we saw no traces of deer or musk oxen' (quoted by Stenton 2014: 519; and see Cavell 2009). However, in a personal communication, Dr D. Stenton, Director of Heritage, Government of Nunavut, has informed the authors that whilst game is scarce on the northwest coast of King William Island in winter and spring (Stenton, personal communication, 31 May 2015), Schwatka observed some seal and caribou in the area in late spring and summer and abundant game at that time on the south coast (see Klutschak 1987: 100 106). It would, however, have entailed a very arduous trek from the ships to procure it. Bones of wild fowl were found at campsites but the cooked flesh of the eider duck and ptarmigan contains only 0.3 and $0.5 \mathrm{mg} / 100 \mathrm{~g}$ of vitamin C, respectively (Graci and Smith 1979), so that very large numbers would have been required to contribute materially to the crews' needs. Moreover, as noted above, even if fishing had been successful, very large catches would have been required due to the small vitamin $\mathrm{C}$ content of the flesh of cod and Arctic char.

It is assumed that the Franklin expedition entered the winter of 1847 with 125 men alive, reducing to 105 by April 1848, making a mean crew size of 115 men over that period. To meet the minimum requirement of 10mg of vitamin $\mathrm{C}$ to prevent scurvy in sedentary men, the available food would have had to provide a total of $1150 \mathrm{mg}$ per day, or $4600 \mathrm{mg}$ to provide the 40 $45 \mathrm{mg}$ safety margin described earlier. It is questionable whether that total could be achieved. For example, if half of the minimum vitamin $\mathrm{C}$ requirement were derived from vitamin-rich offal such as seal liver, then with a mean content of $13.6 \mathrm{mg} / 100 \mathrm{~g}$ after light boiling to make it palatable, a daily total of $4.2 \mathrm{~kg}$ of liver would be required. The average weight of a harp seal (Pagophilus groenlandicus) liver is $1.3 \mathrm{~kg}$ (Shahidi 1998) so the expedition would have had to kill three seals every day to provide half their minimum needs. It is doubtful that other expeditions consistently achieved this level of success in hunting and there is no reason to assume that the Franklin expedition was different in this respect.

\section{Evidence of scurvy in the Franklin crew}

Mays and others (2015) have observed that many chroniclers of the Franklin expedition have asserted that scurvy played a significant role in the disaster but with little supporting evidence. For example, Cyriax (1939: 135) stated that the role of scurvy 'admits of very little doubt', his conclusion apparently being based on evidence that scurvy commonly occurred after two Arctic winters and the supposed deaths of most of Franklin's men by autumn of 1848. The data from the Sick books confirm the appearance of scurvy after two winters although it occurred after only one winter on the search expeditions of Ross (1848-1849) and Belcher (1852-1854).

The permafrost-preserved bodies on Beechey Island and the skeletal remains on King William Island provide the potential for direct evidence of the disease in Franklin's men. Notman and others (1987) stated explicitly that their detailed autopsies of John Hartnell and William Braine showed no evidence of scurvy so that it is quite unclear what evidence led Cookson (2000: 82) to assert that Braine's body bore 'the classic signs of scurvy.' Mays and others (2015) have re-examined the skeletal remains representing three or more men recovered by Beattie (1983) and Beattie and Savelle (1983) and a skeleton identified as probably that of Harry Goodsir, assistant surgeon of Erebus (Mays and others 2011). They have also reviewed the data from bones representing eleven or more men published by Keenleyside and others (1997). There is scope here only to summarise their highly detailed analysis.

Broadly, it was concluded that there was little evidence of pathological changes in the skeletal remains. Subperiosteal lesions in a tibia and femur had been considered consistent with scurvy by Beattie and Savelle (1983) but Mays and others (2015) observed that they may also result from other trauma and infection. They also noted that only a small number of the bones recovered by Keenleyside and others (1997) showed evidence of periostitis which, while associated with scurvy, the latter authors had ascribed to infection or trauma. Periodontal disease and ante-mortem tooth loss were also evident, and are associated with scurvy, but may also be caused by other conditions. None of the remains, including Goodsir's skeleton, showed evidence of staining of haematomas that is known to endure in Arctic burial conditions. More recently, Stenton and others (2015) have reported the analysis of newly-discovered remains of some three men which also show healed periostitis on tibiae and ante-mortem tooth loss but they, too, note that these signs may not be solely indicative of scurvy.

In the case of Goodsir's skeleton, porotic areas in the interdental septa of the posterior parts of the maxillary dental arch were not considered to be conclusive signs of scurvy and no other bones showed evidence of periosteal new bone. Mycobacterium tuberculosis could not be detected. Rather, an infection in the maxilla was considered as possibly contributing to Goodsir's death. The remains had been accorded formal burial which might imply that 
Goodsir died while the Expedition continued to enjoy the status of being 'All well'. Moreover, Table 3 indicates that, as an officer, Goodsir would be relatively less likely to have suffered scurvy.

Geber and Murphy (2012) and Mays and others (2015) note the interpretive complication that arises from the fact that vitamin $\mathrm{C}$ is necessary for the ossification of periosteal haematomas which may indicate that the individual has suffered from scurvy. Such ossification will occur when the vitamin is reintroduced to the diet after a period of absence; in other words, the remains of men who suffered severely from scurvy but died before the re-introduction of the vitamin may show little or no skeletal signs of the disease. Thus, skeletal remains which show little evidence of scurvy may imply that there was no dietary lack of vitamin $\mathrm{C}$ and that death was caused by other factors, or that vitamin $\mathrm{C}$ was not reintroduced prior to death. Mays and others note, however, that animal models show that only small amounts of vitamin $C$ need be reintroduced to the diet to provoke ossification.

Mays and others (2015) concluded that their reanalysis produced little evidence of scurvy in the remains of Franklin's men. However, in their carefully balanced discussion they noted that the sample size was relatively small and in this context alluded to the statistical epigram that 'absence of evidence is not evidence of absence' (Altman and Bland 1995). Small samples carry the selfevident risk that they may not represent the larger 'population' from which they are drawn. Scurvy was seen to have occurred to a greater or lesser degree in every ship of the search squadrons that spent more than two winters in the Arctic and, as explained, the incidence was clearly greater than formally recorded. If those ships are valid comparators then it would seem probable that the disease would have affected some of Franklin's men by the end of 1847 or early 1848 . However, there is no evidence that Franklin's crews suffered the early ravages of scurvy seen in Ross's 1848-1849 expedition (the Victory Point record stated 'All well' after two years) or the starvationexacerbated scurvy of McClure's Investigator (there was no evidence of food shortage at desertion of the ships; Woodman 1991: 100). The present data might therefore support the conclusion of Mays and others (2015) that there is no clear evidence that scurvy was incapacitating at the time of deserting the ships.

\section{Lead poisoning}

Lead poisoning from solder used to seal canned provisions has been proposed to have affected the physical health and mental function of Franklin's crews (Beattie and Geiger 1987; Keenleyside and others 1996, 1997; Kowal and others 1989), some of whose remains have shown high levels of lead relative to those of today. The levels of lead are not in doubt but its source and whether it caused poisoning leading to the failure of the expedition can be questioned on a number of grounds (see Amy and others 1986; Banfield 1960; Drummond and Lewis 1938; Farrer 1993; Fordham 1991; Martin and others 2013;
Millar and others 2015; Notman and others 1987; Powell 1992; Shirley 1992).

The crews of all of the search ships had much greater lead exposure than is permitted today. As in the case of their canned provisions, their canisters of pemmican were sealed with lead solder by the Deptford Yard (ADM 114/21, 9 January 1850). Royal Naval medicine chests contained lead-based medications (His Majesty's Stationery Office 1835) for conditions as diverse as dysentery, gonorrhoea and irritation of the gums in scurvy (Millar and others 2015), and 'Goulard's Extract' (sub-acetate of lead) was issued to sledge parties as an astringent (Pickthorn 1851). Lead piping introduced ingestion of lead from drinking water (Farrer 1993; Battersby 2008; Battersby and Carney 2011) particularly when the practice of melting snow produced 'soft' water having a plumbosolvent effect on pipes (Troesken 2006). Investigator was at least one ship to be fitted with 'Bowser's Fire-hearth' with attached 'snow tank' to melt snow for drinking water (Armstrong 1857: 608).

The neurological and gastro-intestinal signs and symptoms of lead poisoning were described in great detail in medical textbooks and journals of the time (Elliotson 1839; Hooper 1839; London Medical Gazette 1836; Thomson 1822) and particularly in Turnbull's (1806) text written specifically for Royal Naval surgeons. No surgeon recorded or suspected lead poisoning, or reported consistent neuro-cognitive signs and symptoms.

In the case of gastro-intestinal illness, the Sick books permit detailed examination of colic, constipation and dyspepsia which are classically associated with lead poisoning. Table 5 shows the numbers with those symptoms, and the days spent on the Sick book until discharged (note that being recorded in the Sick book did not mean being unable to perform one's normal duties). It is evident that the vast majority of cases were acute in nature: all but one case of colic and dyspepsia, respectively, resolved within 15 days. The one case of colic resolved within 25 days, and the case of dyspepsia and three of constipation resolved within 50 days. In chronic poisoning, such symptoms are largely persistent and often incapacitating (Gordon and others 2002; Needleman 2004). Symptoms were recurrent, after variable intervals, in only 17 individuals. As lead ingestion might be expected to have been greater during winter when plumbo-solvent snow-melt was used for drinking water, analysis was also made of these symptoms as a function of the time of year. Fifty-nine of the cases shown in Table 5 (52\%) occurred from October to March, while 55 occurred from April to September (48\%): the difference is not remotely significant.

Whilst the symptoms above can be associated with lead poisoning, they are also seen in other conditions that may commonly, recurrently or persistently affect the gastro-intestinal tract. Nonetheless, lead ingestion was inevitably present on these ships so that some of the persistent cases may have reflected intolerance of the metal in sensitive individuals (Milković-Kraus and others 1997). However, unless some exceptional source of lead 
Table 5. Number of cases of colic, constipation and dyspepsia as a function of the time to discharge from treatment, and the cumulative percentage of those discharged in parentheses.

\begin{tabular}{|llllllll|}
\hline Days to discharge & $1-5$ & $6-10$ & $11-15$ & $16-20$ & $21-25$ & $26-30$ & $31-50$ \\
\hline Colic & $13(77)$ & $16(94)$ & $16(94)$ & $16(94)$ & $17(100)$ & - & - \\
$\mathrm{N}=17$ & & & & & & & \\
Constipation N=30 & $19(63)$ & $24(80)$ & $26(87)$ & $26(87)$ & $27(90)$ & $29(97)$ & $30(100)$ \\
$\begin{array}{l}\text { Dyspepsia } \\
\mathrm{N}=67\end{array}$ & $37(55)$ & $57(85)$ & $66(99)$ & $66(99)$ & $66(99)$ & $66(99)$ & $67(100)$ \\
\hline
\end{tabular}

existed on Franklin's ships, the probability would be that the ingestion of the metal was similar across the search ships and Franklin's crews and that any effects on the latter during the three years leading to desertion of the ships would parallel those shown here. On this basis, it would seem improbable that incapacitating effects of lead poisoning occurred prior to desertion of the ships. It should be noted that the autopsies conducted on the permafrost-preserved corpses at Beechey Island stated explicitly that there was no evidence of calcification of the basal ganglia of the brain which is characteristic of chronic lead poisoning (Notman and others 1987) and nor was 'Burton's line' (Burton 1840) reported in the oral cavity (a bluish-grey line commonly observed on the gingiva in lead poisoning: Pearce 2007). On this evidence, Amy and others (1986) concluded that it was uncertain whether the elevated levels of lead were significant to the fate of the expedition but their conclusion is rarely cited (an exception is Woodman 1991: 338). It should be emphasised that none of the remains of any other Arctic crews have been examined to determine whether they had similar lead burdens to Franklin's men so that there is no evidence that the latter levels were atypical of Arctic crews of the time.

\section{Potential deficiency of vitamin B1}

The crew of Investigator was starving and may have suffered other nutritional deficiencies. In addition to the ravages of scurvy, one man 'was in a dreadful state; his flesh would retain an impression, if touched with the finger, like dough or putty; his legs were swollen to twice their natural size' (McDougall 1857: 223). The marked oedema seen in twelve men one of whom died of cardiac failure, and widespread syncope amongst others, might reflect the consequences of thiamine deficiency (vitamin B1). Guly $(2012,2013)$ has described how the symptoms of thiamine deficiency were often ascribed incorrectly to scurvy in the Antarctic expeditions of the 19th and early 20th centuries, so that similar misdiagnosis may have affected the Arctic crews. The relevance to the Franklin expedition lies in Guly's (2012: 160, 161) observation that, on some Antarctic expeditions, oedema and associated heart failure consistent with 'wet beri-beri' occurred more often in officers because their bread was made from more refined flour from which the thiamine-rich husk and germ were removed. The victualing correspondence for Erebus and Terror contains calculations resulting from concern as to how long the missing Expedition's stocks of flour might last (ADM 114/7, 19 February 1847) but does not state whether different qualities of flour were supplied. In a personal communication, Dr Simon Mays (Historic England and University of Southampton) has also observed that passive hyperaemia associated with cardiac failure tends to elicit subperiosteal new bone production so that one might expect to find such new bone if oedema of the lower legs was common. This consequence of cardiac illness might then be misattributed to scurvy (Mays, personal communication (email), 4 November 2015).

There is no evidence of symptoms consistent with thiamine deficiency solely amongst officers of the search ships so that there may be no implication for the disproportionate deaths of Franklin's officers. However, Guly's (2012, 2013) demonstration of the confusion between symptoms of scurvy and those of vitamin B1 deficiency, and the observations concerning oedema and periosteal new bone, would suggest that close analysis of the Sick books of the Arctic discovery ships might lead to a more accurate view of the extent to which scurvy alone affected the patterns of morbidity and mortality.

\section{Botulism}

Cookson (2000) and Horowitz (2003) have proposed that the expedition was fatally weakened by botulism. The bacterium Clostridium botulinum was proposed by Cookson to have been present in the canned provisions because their known hasty preparation (ADM 114/17, 4 April 1845) by the manufacturer, Goldner, was supposed to have fostered the conditions for the bacterium to produce a neurotoxin which causes death by paralysing the muscles of respiration. Whilst Goldner was associated with a later scandal concerning the putrid contents of his products, there is no evidence that such provisions were supplied to the expedition (Lloyd and Coulter 1963: 96-102; Domville 1853). The search squadrons were supplied by Goldner and by Gamble and Co. with some provisions which were unfit for consumption (ADM 55/44; ADM 101/99/4; ADM 101/117/3). For example, the $230 \mathrm{~kg}$ of unfit preserved meats on Investigator were supplied by Gamble and had been produced in haste to meet the departure date (in fact, they were not supplied in time and had to be collected en route; Collinson 1889: 38). None of these well-documented failures was associated with illness. 
Horowitz (2003) observed that the high salinity and nitrite contents of some of the preserved foods would have inhibited germination of the bacterium spores. Rather, he proposed that meat procured from hunting was contaminated with botulism type $\mathrm{E}$ which is found in the Arctic environment and that it was the preferential serving of fresh meat to Franklin's officers that explained their disproportionate death rate. The difficulty with this explanation is, again, that there was no evidence of botulism amongst the search crews who also procured fresh meat and, further, that when fresh meat was available it was not the exclusive preserve of the officers but was served to all hands (see Armstrong 1857: 322; Barr 1992: 31).

An 'uncommon' but unnamed genus of Clostridium was isolated from the bowel of William Braine who died during the expedition's winter at Beechey Island (Beattie and Geiger 1987:239). As Clostridia colonise the human bowel and do not necessarily cause illness the discovery of the bacterium may not be of significance. The Sick books provide no evidence of botulism in the search crews and there would seem no reason to assume that the condition occurred amongst Franklin's men.

\section{The deaths of Franklin's crews in context}

If, like Parry, one must 'deal with probabilities' which are defined, however imperfectly, by the experiences of the search squadrons, then the data of Table 2 suggest that some deaths of Franklin's men would have been associated with respiratory conditions, cardiac disorders and infections resulting from injuries. It might also seem probable that scurvy affected some of Franklin's men but, for reasons discussed above, may not have been of significance at the time of deserting the ships.

The number of deaths on Franklin's ships should be put in context. It is known that by 11 June 1847 , Franklin, Braine and Hartnell of Erebus, and Torrington of Terror, were dead. Others may have died by that date but were unrecorded. These known deaths over 25 months represent $4.5 \%$ and $1.6 \%$ of the complements of Erebus and Terror, respectively, and compare with $6.2 \%$ and $4.6 \%$ deaths on Ross's Enterprise and Investigator, respectively, over 22 months, and $13.3 \%$ deaths on Intrepid over 26 months. On this basis, two years into their commission, deaths on Erebus and Terror were exceeded by those on three of the search ships.

The $13.3 \%$ deaths aboard Intrepid after 26 months are not significantly different from the total of $18.6 \%$ deaths aboard Erebus and Terror after 35 months (p = 0.677). An obvious difference, however, is that the deaths on Intrepid did not include officers but were amongst the other ranks, whereas at this point on the Franklin expedition it is known that nine officers had died. If the deaths on Intrepid are considered only within the context of the other ranks, then the deaths after 26 months represent $15.4 \%$ which is slightly greater than the $14.2 \%$ among other ranks on the Franklin expedition after 35 months. The implication then is that the anom- aly is the high proportion of deaths among Franklin's officers.

The data from the search ships showed that four officers died from murder, suicide and tuberculosis. Amongst Franklin's officers, murder and suicide can only be conjecture. Franklin's death aged 61 was perhaps not exceptional, being similar to four naval contemporaries who also died in their early- to mid-sixties: Austin (64), McClure (67), Parry (64) and Ross (61). Men of Franklin's age were most likely to die of cardiovascular or lung disease rather than pulmonary tuberculosis which had a much lower incidence in that group (Woods and Shelton 1997). Prior to departure, Franklin is known to have suffered poor health that was attributed to persistent 'influenza' (Franklin 1845). However, Stephen Stanley, surgeon of Erebus, wrote to Sir John Richardson from the Whalefish Islands on 12 July 1845 to confirm that Franklin had rallied and was then 'in very best health' (Stanley 1845). Whether the 'influenza' had been a portent of a more serious latent condition must be conjecture. It was noted that Goodsir may have died of a dental infection and that tests for tuberculosis were negative. Of the remaining seven officers who died, it must be conjecture whether any succumbed to tubercular disease as did two officers of the search ships, but tuberculosis was the commonest cause of death of men in their age group and no respecter of social class, and it was observed that its presence in the search crews may be underestimated. As noted above, tubercular disease was suspected in the able seaman and Royal Marine of Franklin's expedition who died at Beechey Island (Notman and others 1987).

Lieutenant Graham Gore of Erebus is known to have died between May 1847 and April 1848: he was sufficiently healthy in May 1847 to lead a party of men on a mission that may have involved hunting or surveying parts of King William Island. It is entirely possible that Gore succumbed to illness but, as officers typically enjoyed superior health to other ranks, the deaths of largely healthy men might more probably arise from injury or mishap. The Sick books show no evidence of a health factor that selected against officers.

The objectives of the expedition and the circumstances that it encountered may provide insight. In a personal communication, Mr Jonathan Moore, senior underwater archaeologist, Parks Canada, has observed that as the primary objectives were to navigate a passage, conduct surveying and gather scientific data it is likely that the officers would have felt bound to fulfil these duties while beset and thus exposed themselves to hazards. Their endeavours would have involved sledging parties and, when possible, perhaps the use of boats to travel between the ships and King William Island or to follow other leads through the ice (Moore, personal communication (email), 13 November 2015). It must be conjecture but it would require only a single party composed principally of officers to be involved in the capsizing of a boat, or a sledge falling through the ice, to contribute to their disproportionate death rate. On 
Resolute, de Bray and McDougall recorded officers being involved in several such incidents which were fortunate not to be fatal, and de Bray observed that hunting was made 'very dangerous' by precarious ice conditions in summer (Barr 1992: 59, 62, 131, 201; McDougall 1857: 291, 297). The Inuit reported witnessing the upset of a boat which had been operating from a beset ship and which resulted in the drowning of three men (Woodman 1991: 226, 231) but, whilst such an event is not known to have affected other expeditions, it cannot be linked with any certainty to Franklin's crews during the critical winter of 1847 to 1848 .

The expedition also endured lengthy entrapment in the pack ice, far from land that, in any case, probably could not provide sufficient game for their needs (Cavell 2009). The winters while beset are known to have been intensely cold (Alt and others 1985; Gilpin 1850 ) and therefore exposed the crews to greater risk of fatal accidents and of succumbing to exposure because operations away from the ships were made more arduous. Cyriax (1939) and Markham (1921) speculated that the officers deliberately exposed themselves to greater risk while hunting to provide food for the others and paid a fatal price for their altruism. This 'heroic' proposal may have a basis in fact and was true of other expeditions. Hunting was generally led by officers who were often exhausted by its demands (McDougall 1857: 278). The consequences of such debility, and a fatal accident involving a hunting party, might contribute to their disproportionate deaths. For example, the extreme cold would cause gun barrels to explode when fired during hunting: on Investigator, Armstrong escaped serious injury, but on Resolute one officer was severely wounded and another's hand was 'shattered'. McDougall almost shot himself through the head when he slipped while carrying a loaded gun on Resolute (McDougall 1857: 375, 399, 401) but a petty officer on Investigator was lucky to survive when a musket, fortunately charged only with powder, was accidentally fired into his lower abdomen (Armstrong $1853,1857)$. The aggressive nature of quarry such as the muskox also posed a risk (see Barr 1992: 64).

Franklin's ships were beset with 126 men to feed; the officers of Investigator, hunting for food, failed to support half that number. Franklin's officers may have taken more risks when hunting given the size of the challenge they faced. The problem was summed up by Kellett (1853: 88) when explaining the need, while beset at Melville Island, to send some of Resolute's crew to the main Belcher squadron: 'Their only fault is that they eat'.

Men were discovered near death due to exposure after becoming lost in white-out conditions when negotiating even short distances between beset ships or when separated from hunting parties (McDougall 1857: 192, 291, 359; Osborn 1856: 229, 230). Only one death was associated directly with such activities (gangrene on Resolute) so perhaps these crews were particularly lucky, although luck deserted Lieutenant J.R Bellot of the support ship HMS Phoenix who drowned while delivering despatches to the Belcher squadron. It is very likely that the Franklin crews undertook such activities, and perhaps they, too, were lucky. They were, however, beset in a more hazardous position which, for the reasons above, may have exposed them to greater risk.

The common use of gunpowder to blast beset ships free of the ice presented an additional hazard. Armstrong (1857: 433) described the 'tremendous' shock wave caused by the desperate use of 'the largest charge ever used in ice navigation' $(114 \mathrm{~kg}$ ) in an attempt to free Investigator. Similar attempts with Resolute succeeded in shattering the crockery on board (McDougall 1857: 426). Franklin's ships took on gunpowder at Greenhithe (Lambert 2009: 159) and, given its widespread use by other ships, it would seem probable that it was used while beset, particularly when tantalisingly close to the charted waters leading to the west. Officers were trained to use gunpowder for such purposes (Armstrong 1857: 244) and were therefore most at risk if there were an accident, but it can only be conjecture whether such an event contributed to deaths amongst Franklin's officers.

The opportunity to 'invalid-out' sick crew is a third factor to distinguish the Franklin expedition from Investigator and Enterprise. Franklin had a 55-day opportunity between departure and final contact at Greenland with the British transport ship Baretto Junior in which to send back men who were ill. After that, sick men would have to remain on board either to recover, become incapacitated or die. Table 6 shows that five men were sent back with unspecified illness (Cyriax 1939). In the same period McClure dispensed with two men, one suffering an unspecified but presumably serious digestive disorder, and another with cardiac disease. Both conditions may have proved fatal had they remained with the ship. In the further 139 days before final contact with HMS Herald, he dispensed with one man having a 'tubercular tumour' (probably scrofula) likely to be fatal and three men having conditions likely at least to be incapacitating. Collinson had a further 483-day period to dispense with cases of tuberculosis and haemorrhage, likely to be fatal, and two cases of syphilis and hernia likely to be incapacitating. If such cases had remained on board then death rates on Investigator and Enterprise would have been closer to those on Franklin's ships. However, these considerations do not explain the high death rate amongst Franklin's officers.

\section{Conclusion}

Evidence from the Sick books may give some insight to events aboard Franklin's ships in the years prior to their desertion. It is proposed that the general pattern of morbidity and mortality on Erebus and Terror, at least through the first two years, may not have differed significantly from that aboard the search squadrons. Even after three years, the total deaths on Franklin's ships were not significantly greater than those on HMS Intrepid of the 
Table 6. The number of men discharged or otherwise lost to the complements of HMS Enterprise (under Collinson), Investigator (under McClure) and Erebus and Terror. First, within the 55-day opportunity available to Franklin between departure and final contact with a British supply ship; secondly within the further 139-day and 483-day periods available to McClure and Collinson, respectively. The data shown for Enterprise and Investigator are drawn from their surgeons' Sick books with the exception of * source: Barr (2007).

\begin{tabular}{|c|c|c|c|}
\hline Ships & Enterprise & Investigator & Erebus and Terror \\
\hline $\begin{array}{l}\text { Number of men } \\
\text { discharged within } 55 \\
\text { days of departure }\end{array}$ & $\begin{array}{l}\text { Scurvy }=1 \\
\text { Syphilis }=1 \\
\text { 'Disgraced' =1 } \\
\text { Total = } 3\end{array}$ & $\begin{array}{l}\text { Dyspepsia = } 1 \\
\text { Endocarditis }=1 \\
\text { Total }=2\end{array}$ & $\begin{array}{l}\text { Unspecified illness }=5 \\
\text { Total }=5\end{array}$ \\
\hline $\begin{array}{l}\text { Number of men } \\
\text { discharged or died } \\
\text { after } 55 \text { days and by } \\
\text { time of final } \\
\text { opportunity to } \\
\text { discharge as invalid }\end{array}$ & $\begin{array}{l}\text { Final opportunity with } \\
\text { HMS Plover on } 10 \text { July } \\
1851 \text { (after } 483 \text { days) } \\
\text { Epistaxis }=1 \\
\text { Hernia }=1 \\
\text { Syphilis }=2 \\
\text { Sudden death }=1 \\
\text { Tuberculosis }=1 \\
\text { Murdered }=1 \\
\text { Suicide }=1 \\
\text { Disciplinary }=1 \\
\text { Total }=10\end{array}$ & $\begin{array}{l}\text { Final opportunity with } \\
\text { HMS Herald on } 31 \text { July } \\
1850 \text { (after } 139 \text { days) } \\
\text { Pneumonia }=1 \\
\text { Rheumatism }=1 \\
\text { Syphilis }=1 \\
\text { Tubercular tumour }=1 \\
\text { Total }=4\end{array}$ & $\begin{array}{l}\text { Final opportunity was at } \\
55 \text { days from departure }\end{array}$ \\
\hline $\begin{array}{l}\text { Other losses and } \\
\text { replacements }\end{array}$ & $\begin{array}{l}\text { Deserted at Hong Kong } \\
\text { but replaced from HM } \\
\text { ships and local jail }=10^{*}\end{array}$ & $\begin{array}{l}\text { Recruited from HMS } \\
\text { Herald to make up } \\
\text { losses }=3\end{array}$ & Nil \\
\hline
\end{tabular}

Belcher squadron, although the disproportionate death rate among Franklin's officers remains a clear anomaly.

The evidence from the search ships argues against the significance of lead poisoning on Franklin's ships unless it can be demonstrated that there was an anomalously higher exposure to the metal than on the similarly equipped and provisioned search ships. Tuberculosis would almost certainly have been present but may not have caused significant mortality. The evidence of scurvy in the search ships was ascribed in part to the preparation and declining potency of the lemon juice. If they are valid comparators it would seem probable that scurvy would have affected some of Franklin's men but the disease would not have contributed to the disaster prior to deserting the ships, thus supporting the direct skeletal evidence that would not confirm scurvy as a significant factor. There is no evidence to suggest that botulism was present.

The disproportionate deaths of officers cannot be explained by health factors but may be ascribed to accidental causes, perhaps resulting from hazards inherent in their pursuit of the navigational and scientific objectives of the expedition and the burden placed upon them to hunt in the most arduous circumstances. The intense cold of the final winter and the isolated position of the ships in a hostile environment would have made survival difficult for all the crew. Equally, the expedition may have encountered so unusual a set of circumstances as to remain unimagined.

The contents of the recently-discovered wreck of HMS Erebus are unknown at the time of writing, but Harris (2014) has stated that if any of the expedition's records were stored securely on board then the underwater conditions are such that they may have been preserved in a legible condition. If a Sick book has survived it may provide conclusive answers to the questions surrounding the expedition's last year on board and put an end to further speculation.

\section{Acknowledgements}

The authors are most grateful to two anonymous reviewers for their detailed and constructive comments and suggestions concerning the medical and historical content of this paper. They are also most grateful to: Dr Simon Mays of Historic England and University of Southampton for advice concerning details of his published research and observations on cardiac illness, oedema and formation of periosteal new bone; Mr. Jonathan Moore, senior underwater archaeologist, Parks Canada, for observations concerning the duties and activities of Franklin's officers that might explain their disproportionate death rate; Mrs. Carol Parry, library and heritage manager of the Royal College of Physicians and Surgeons of Glasgow for information concerning the nineteenth-century medical curriculum; Mr. Frank Pinhorn, executive director, Canadian Sealers Association, for information concerning Dr Shahidi's research; Dr Douglas Stenton, Director of Heritage, Government of Nunavut, for information concerning historical evidence of game along the shores of King William Island; the University of Glasgow Archive Services for permission to publish the details of the naming of HMS Investigator discovered in the papers of Scotts of Greenock by the late Dr J.F. Robb. 


\section{Financial support}

This work received no specific grant from any funding agency, commercial or not-for-profit sectors but was supported through the facilities of the University of Glasgow's College of Medical, Veterinary and Life Sciences and the College of Science and Engineering.

\section{Conflict of interest}

None

\section{References}

ADM 38/7579 Muster book of HMS Assistance and steam tender HMS Intrepid: 1850-51. London: National Archives.

ADM 38/7580 Muster book of HMS Assistance and steam tender HMS Pioneer. 1852-54. London: National Archives.

ADM 38/8387 Muster book of HMS Investigator. 1848-49. London: National Archives.

ADM 38/8863 Muster book of HMS Resolute and steam tender HMS Intrepid: 1852-54. London: National Archives.

ADM 5/44 Admiralty: supplementary logs and journals of ships of exploration. Enterprise: log kept by Captain James C. Ross: surveying Arctic and North America, 4 February 1848-26 November 1849.

ADM 114/17 Navy Board and Admiralty: Victualling Department. Expeditions: Arctic and Antarctic. Victualing records and correspondence: expedition of 1845 commanded by Captain Sir John Franklin (HM Ships Erebus and Terror) and expedition of 1850 commanded by Captain Horatio Austin (HM Ships Assistance and Resolute and steam tenders Intrepid and Pioneer). London: National Archives.

ADM 114/18 Navy Board and Admiralty: Victualing Department. Expeditions: Arctic and Antarctic. Victualing records and correspondence: expedition of 1852 commanded by Captain Sir Edward Belcher (HM Ships Assistance and Resolute and steam tenders Intrepid and Pioneer). London: National Archives.

ADM 114/19 Navy Board and Admiralty: Victualling Department. Expeditions Arctic and Antarctic 1852-1856. Miscellaneous correspondence. Letter of 26 February 1853 (quotes verbatim Sir John Ross's letter of 18 March 1850 which is not included). London: National Archives.

ADM 114/21 Navy Board and Admiralty: Victualling Department. Expeditions: Arctic and Antarctic. Victualing records and correspondence: expedition of 1849 commanded by Captain Richard Collinson (HM Ships Enterprise and Investigator). London: National Archives.

Admiralty Committee on Scurvy. 1877. Report of the committee appointed by the Lord Commissioners of the Admiralty, to enquire into the causes of scurvy in the recent Arctic expedition; the adequacy of the provision made by the Admiralty in the way of food, medicine and medical comforts; and the propriety of the orders given by the commander of the expedition for provisioning the sledge parties. Presented to both Houses of Parliament by command of Her Majesty, 1877. London: Harrison and Sons for Her Majesty's Stationery Office. 98.

Alt, B.T., R.M. Koerner, D.A. Fisher and other. 1985. Arctic climate during the Franklin era, as deduced from ice cores. In: Sutherland, P. D. (editor). The Franklin era in Canadian Arctic history 1845-1859. Ottawa: National Museum of Man (Mercury Series, Archaeological Survey of Canada 131): 6992.

Altman, D.G. and J.M. Bland. 1995. Absence of evidence is not evidence of absence. British Medical Journal 311: 485.
Amy, R., R. Bhatnagar, E. Damkjar and other. 1986. The last Franklin expedition: report of a post-mortem examination of a crew member. Canadian Medical Association Journal 135: 115-117.

Anderson, R. 1855. Sick book of HMS Enterprise, 14 December 1849 to 24 May 1855. London: National Archives ADM 101/99/5.

Armstrong, A. 1853. Sick book of HMS Investigator, 1 January 1850 to 3 June 1853. London: National Archives ADM $101 / 250$

Armstrong, A. 1857. A personal narrative of the discovery of the north-west passage. London: Hurst and Blackett.

Armstrong, A. 1858. Observations on naval hygiene and scurvy: more particularly as the latter appeared during a polar voyage. London: John Churchill.

Armstrong, A. and W.J. Domville. 1853. Letter to Captain Henry Kellett, 23 May 1853. Report of a medical inspection of the crew of HMS Investigator. Sick book of HMS Investigator, 1 January 1850 to 3 June 1853. London: National Archives ADM 101/250.

Artés-Hernández, F., F. Rivera-Cabrera and A.A. Kader. 2007. Quality retention and potential shelf-life of fresh-cut lemons as affected by cut type and temperature. Postharvest Biology and Technology 43: 245-254.

Banfield, F.H. 1960. The oldest canned food in the world? New Scientist, 5 May 1960: 1138-1140.

Baron, J.H. 2009. Sailors' scurvy before and after James Lind a reassessment. Nutrition Reviews 67: 315-322.

Barr, W. 1992. A Frenchman in search of Franklin. De Bray's Arctic journal, 1852-1854. The journal kept by Emile Frédéric de Bray, (translator and editor W. Barr). Toronto: University of Toronto Press.

Barr, W. 2007. Arctic hell ship. The voyage of HMS Enterprise 1850-1855. Edmonton: University of Alberta Press.

Battersby, W, 2008. Identification of the probable source of the lead poisoning observed in members of the Franklin Expedition. Journal of the Hakluyt Society. 1-10 September 2008. URL: http://www.hakluyt.com (accessed 11 July 2013).

Battersby, W. and P. Carney. 2011. Equipping HM Ships Erebus and Terror, 1845. International Journal for the History of Engineering and Technology 81: 159-180.

Beattie, O. 1985. Elevated bone lead levels in a crewman from the last Arctic expedition of Sir John Franklin. In: Sutherland, P. D. (editor). The Franklin era in Canadian Arctic history 1845-1859. Ottawa: National Museum of Man (Mercury Series, Archaeological Survey of Canada 131): 141-148.

Beattie, O. and J. Geiger. 1987. Frozen in time: the fate of the Franklin expedition. London: Bloomsbury.

Beattie, O.B. and J.M. Savelle. 1983. Discovery of human remains from Sir John Franklin's last expedition. Historical Archaeology 17: 100-105.

Belcher, E. 1855. The last of the Arctic voyages: being a narrative of the expedition of HMS Assistance. 2 vols. London: Reeve.

Bell, B. 1881. Lieut. John Irving R.N. of H.M.S. 'Terror' in Sir John Franklin's last expedition to the Arctic regions. A memorial sketch and letters. Edinburgh: David Douglas.

Bender, A.E. 1981. The history and implications of processed food. In: Watt, J., E.J. Freeman and W.F. Bynum (editors). Starving sailors. The influence of nutrition upon naval and maritime history. Bristol: John Wright and Sons (for the National Maritime Museum): 117-122.

Bennett, A. H. and D.J. Tarbert. 1933. Vitamin C in citrus juices. Biochemical Journal 27: 1294-1301.

Bradford, A.R. 1851. Sick book of HMS Resolute, 28 February 1850 to 9 October 1851. London: National Archives ADM $101 / 117 / 3$. 
Brandt, A. 2011. The man who ate his boots: Sir John Franklin and the tragic history of the northwest passage. London: Jonathan Cape.

Burton, H. 1840. A remarkable effect of lead upon the human gums produced by the absorption of lead. Medico-Chirurgical Transactions 23: 63-79.

Carpenter, K. J. 1986. The history of scurvy and vitamin C. Cambridge: Cambridge University Press.

Cavell, J. 2009. Going native in the north: reconsidering British attitudes during the Franklin search, 1848-1859. Polar Record 45: 25-35.

Collinson, R. 1889. Journal of HMS Enterprise, on the expedition in search of Sir John Franklin's ships by Behring Strait, 185055. (editor T.B. Collinson). London: Sampson Low, Marston, Searle and Rivington.

Cookson, S. 2000. Ice blink. New York: John Wiley.

Crimmin, P. 2013. The Sick and Hurt Board and the problem of scurvy. Journal for Maritime Research 15: 47-53.

Cyriax, R. J. 1939. Sir John Franklin's last Arctic expedition: a chapter in the history of the Royal Navy. Plaistow and Sutton Coldfield: Arctic Press (1997 reprint of the 1939 edition).

Cyriax, R. J. 1947. A historic medicine chest. Canadian Medical Association Journal 57: 295-300.

Cyriax, R. J. 1969. The unsolved problem of the Franklin expedition records supposedly buried on King William Island. The Mariner's Mirror 55: 23-32.

Domville, W.T. 1853. Journal of W.T. Domville, surgeon, HMS Resolute, 1852-1853. Greenwich: National Maritime Museum, JOD/67.

Drummond, J.C. and W.R. Lewis. 1938. The examination of some tinned foods of historical interest. Part 1, historical introduction. Journal of the Society of the Chemical Industry 57: 808-814.

Elliotson, J. 1839. The principles and practice of medicine. Vol. II. London: Joseph Butler.

Fain, O. 2005. Musculoskeletal manifestations of scurvy. Joint Bone Spine 72: 124-128.

Farrer, K.T.H. 1993. Lead and the last Franklin expedition. Journal of Archaeological Science 20: 399-409.

Fordham, D. 1991. Lead poisoning and the Franklin expedition. Polar Record 27: 371.

Franklin, J. 1845. Letters to Jane Franklin, 1 March and 2 April 1845. Cambridge: Scott Polar Research Institute GB 15.

Geber, J. and E. Murphy. 2012. Scurvy in the great Irish famine: evidence of vitamin C deficiency from a mid-19th century skeletal population. American Journal of Physical Anthropology 148: 512-524.

Geraci, J. R. and T.G. Smith. 1979. Vitamin C in the diet of Inuit hunters from Holman, Northwest Territories. Arctic 32: 135139.

Gilpin, J.D. 1850. Outline of the voyage of HMS Enterprise and Investigator to Barrow Straits, in search of Sir John Franklin. Nautical Magazine 19: 8-17.

Gordon, J.N., A. Taylor and P.N. Bennett. 2002. Lead poisoning: case studies. British Journal of Clinical Pharmacology 53: 451-458.

Guly, H. 2012. 'Polar anaemia': cardiac failure during the heroic age of Antarctic exploration. Polar Record 48: 157-164.

Guly, H. 2013. The understanding of scurvy during the heroic age of Antarctic exploration. Polar Record 49: 26-32.

Harris, R. 2014. The discovery of HMS Erebus. London: British Library (Lecture given on 1 December 2014).

His Majesty's Stationery Office, 1835. Regulations and instructions for the medical officers of His Majesty's fleet. London: W. Clowes.

Hooper, R. 1839. Lexicon medicus (7th edn). London: Longman and Orme.
Horowitz, B. Z. 2003. Polar poisons: did botulism doom the Franklin expedition? Journal of Toxicology: Clinical Toxicology 41: 841-847.

Houston, C. S. 1990. Scurvy and Canadian exploration. Canadian Bulletin of Medical History 7: 161-167.

Hughes, R.E. 1975. James Lind and the cure of scurvy: an experimental approach. Medical History 19: 342-351.

Hughes, R.E. 1990. The rise and fall of the 'antiscorbutics'; some notes on the traditional cures for 'land scurvy'. Medical History 34: 52-64.

Illustrated London News. 1852. Report of a lecture to the Royal Geographical Society by Captain Penny: Illustrated London News13 November 1852.

Jones, E. and R.E. Hughes. 1976. Copper boilers and the occurrence of scurvy: an experimental approach. Medical History 20: 80, 81.

Keenleyside, A., X. Song, D. R. Chettle and other. 1996. The lead content of human bones from the 1845 Franklin expedition. Journal of Archaeological Science 23: 461-465.

Keenleyside, A., M. Bertulli and H. C. Fricke. 1997. The final days of the Franklin expedition: new skeletal evidence. Arctic 50 (1): 36-46.

Kellett, H. 1853. Letter to Sir Edward Belcher, 7 May 1853. In: Papers relative to the recent Arctic expeditions in search of Sir John Franklin and the crews of H.M.S. 'Erebus' and 'Terror': presented to both Houses of Parliament by command of Her Majesty. London: Eyre and Spottiswoode for Her Majesty's Stationery Office 1854: 88.

Klutschak, H.W. 1987. Overland to Starvation Cove. With the Inuit in search of Franklin 1878-1880 (translator and editor W. Barr). Toronto: University of Toronto Press. (First published as: 1881. Als Eskimo unter den Eskimos: Eine Schilderung der Erlebnisse der Schwatka'schen FranklinAufsuchungs-Expedition in den Jahren 1878-1880. Vienna: A. Hartleben Verlag).

Kowal, W.A., P.M. Krahn and O.B. Beattie. 1989. Lead levels in human tissues from the Franklin Forensic Project. International Journal of Environmental and Analytical Chemistry 35: 119-126.

Lambert, A. 2009. Franklin: tragic hero of polar navigation. London: Faber and Faber.

Lee, S.K. and A. A. Kader. 2000. Preharvest and postharvest factors influencing vitamin $\mathrm{C}$ content of agricultural crops. Postharvest Biology and Technology 20: 207-220.

Lequin, S., D. Chassagne, T. Karbowiak and others. 2012. Diffusion of oxygen in cork. Journal of Agricultural and Food Chemistry 60: 3348-3356.

Lloyd, C. and J. L. S. Coulter. 1963. Medicine in the Navy 12001900. Vol. IV, 1815-1900. London: E. and S. Livingstone.

London Medical Gazette 1836. Lectures on materia medica, or pharmacology and general therapeutics. Plumbum, or lead. London Medical Gazette 28 May 1836: 309-314.

Lyall, D. 1854. Sick book of HMS Assistance, 16 February 1852 to 15 May 1854. London; National Archives ADM 101/87/8.

Markham, C. R. 1921. The lands of silence, a history of Arctic and Antarctic exploration. Cambridge: Cambridge University Press.

Martin, R.R., S. Naftel, S. Macfie and others. 2013. Pb distribution in bones from the Franklin expedition: synchrotron X-ray fluorescence and laser ablation/mass spectroscopy. Applied Physics A 111: 23-29.

Martinez-Sanchez, A., A. Gil-Izquierdo, M.I. Gil and other. 2008. A comparative study of flavonoid compounds, vitamin $\mathrm{C}$, and antioxidant properties of baby leaf Brassicaceae species. Journal of Agricultural and Food Chemistry 56: 2330-2340.

May, J.M. 2013. Medical aspects of the development of scurvy: past and present. Journal for Maritime Research 15: 95-105. 
Mays, S., A. Ogden, J. Montgomery and others. 2011. New light on the personal identification of a skeleton of a member of Sir John Franklin's last expedition to the Arctic, 1845. Journal of Archaeological Science 38: 1571-1582.

Mays, S., G.J.R. Maat and H.H. De Boer. 2015. Scurvy as a factor in the loss of the 1845 Franklin expedition to the Arctic: a reconsideration. International Journal of Osteoarchaeology 25: 334-344.

McCord, C.P. 1972. Scurvy as an occupational disease. IX scurvy in polar expeditions. Journal of Occupational Medicine 14: 232-235.

McClintock, F.L. 1859. The voyage of the 'Fox' in the Arctic seas: a narrative of the discovery of the fate of Sir John Franklin and his companions. London: John Murray.

McDougall, G. F. 1857. The eventful voyage of HM Discovery Ship 'Resolute' to the Arctic regions in search of Sir John Franklin and the missing crews of HM Discovery Ships 'Erebus' and 'Terror'. London: Longman, Brown, Green, Longmans and Roberts.

Millar, K., A.W. Bowman and W. Battersby. 2015. A re-analysis of the supposed role of lead poisoning in Sir John Franklin's last expedition, 1845-1848. Polar Record 51: 224238.

Milković-Kraus, S., N. Restek-Samaržija., M. Samaržija and other. 1997. Individual variation in response to lead exposure: a dilemma for the occupational health physician. American Journal of Industrial Medicine 31: 631-635.

Needleman, H. 2004. Lead poisoning. Annual Review of Medicine 55: 209-222.

Nevares, I. and M. del Alamo-Sanza. 2015. Oak stave oxygen permeation: a new tool to make barrels with different wine oxygenation potentials. Journal of Agricultural and Food Chemistry 63: 1268-1275.

Norris, J. 1983. The 'scurvy disposition': heavy exertion as an exacerbating influence on scurvy in modern times. Bulletin of the History of Medicine 57: 325-328.

Notman, D.N.H., L. Anderson, O. Beattie and other. 1987. Arctic paleoradiology: portable radiographic examination of two frozen sailors from the Franklin expedition (1845-1848). American Journal of Radiology 149: 347-350.

Osborn, S. (editor). 1856. The discovery of the north-west passage by H.M.S. 'Investigator', Capt. R. McClure, 1850, 1851, 1852, 1853, 1854. London: Longman, Brown, Green, Longmans and Roberts.

Owen, R. 1978. The fate of Franklin. The life and mysterious death of the most heroic of Arctic explorers. London: Hutchinson and Co.

Parry, E. 1850. Letter to Secretary of the Admiralty, 6 February 1850. In: Arctic expeditions; return to, and order of, the honourable the House of Commons, 5 March 1850. London: Her Majesty's Stationery Office.

Pearce, J. M. S. 2007. Burton's line in lead poisoning. European Neurology 57: 118-119.

Pemberton, J. 2006. Medical experiments carried out in Sheffield on conscientious objectors to military service during the 1939-45 war. International Journal of Epidemiology 35: 556558

Phillimore, R.J. 1835. A report of the judgement delivered on the sixth of June, 1835, by Joseph Phillimore, in the cause of Belcher, the wife, against Belcher, the husband. London: Saunders and Benning.

Pickthorn, J. R. 1851. Sick book of HMS Pioneer, 28 February 1850 to 9 October 1851. London: National Archives ADM $101 / 113 / 1$

Powell, B.D. 1992. Lead poisoning and the Franklin expedition. Polar Record 28: 252-253.
Priston, J.L. 1926. The prevention of scurvy in the Navy. Proceedings of the Royal Society of Medicine 19 (War Section): 7-14.

Robertson, J. 1849. Sick book of HMS Enterprise, 3 February 1848 to 26 November 1849. London: National Archives ADM $101 / 99 / 4$.

Robb, J. F. 1993. Scotts of Greenock, shipbuilders and engineers, 1820-1920: a family enterprise. Unpublished PhD dissertation. Glasgow: University of Glasgow GUAS BH1.63 and 64.

Savours, A. 1999. The search for the North West Passage. London: Chatham Publishing.

Savours, A. and M. Deacon. 1981. Nutritional aspects of the British Arctic (Nares) expedition of 1875-76 and its predecessors. In: Watt, J., E. J. Freeman and W. F. Bynum (editors). Starving sailors. The influence of nutrition upon naval and maritime history. Bristol: John Wright and Sons (for the National Maritime Museum): 131-162.

Scott, R.C. 1854. Sick Book of HMS Intrepid, 25 February 1852 to 15 May 1854. London: National Archives ADM 101/105/1.

Scotts of Greenock. 1848. Scotts of Greenock: Ship Builders and Engineers, Letter Book 13, 17 January 1848. Archive Services, Glasgow: University of Glasgow archives GD319/11/1/8.

Shahidi, F. 1998. Seal fishery and product development. St. John's: Science Tech Publishing Company.

Shirley, A. 1992. Lead poisoning and the Franklin expedition. Polar Record 28: 73.

Stanley, S.S. 1845. Letter to Sir John Richardson, 12 July 1845. Cambridge: Scott Polar Research Institute GB 15 Steven [sic] Stanley.

Stein, G.M. 2015. Discovering the north-west passage: the fouryear odyssey of HMS 'Investigator' and the McClure expedition. Jefferson NJ: McFarland and Co.

Stenton, D.R. 2014. A most inhospitable coast: the report of Lieutenant William Hobson's 1859 search for the Franklin expedition on King William Island. Arctic 67: 511-522.

Stenton, D.R., A. Keenleyside and R. W. Park. 2015. The 'Boat Place' burial: new skeletal evidence from the 1845 Franklin expedition. Arctic 68: 32-44.

Thomson, A. T. 1822. The London dispensatory. A practical synopsis of materia medica, pharmacy and therapeutics (3rd edn). London: Longman, Hurst, Rees, Orme and Brown.

Troesken, W. 2006. The great lead water pipe disaster. Cambridge: MIT Press.

Truswell, A. S. and J. Mann. 2012. Vitamins C and E. In: Mann, J. and A. S. Truswell (editors). 2012. Essentials of human nutrition. Oxford: Oxford University Press: 236-245.

Turnbull, W. 1806. The naval surgeon; comprising the entire duties of professional men at sea. London: Richard Philips.

Vale, B. 2008. The conquest of scurvy in the Royal Navy 17931800: a challenge to current orthodoxy. The Mariner's Mirror 94: 160-175.

Vikram, V. B., M. N. Ramesh and S. G. Prapulla. 2005. Thermal degradation of nutrients in orange juice heated by electromagnetic and conventional methods. Journal of Food Engineering 69: 31-40.

Williams, G. 2010. Arctic labyrinth. The quest for the northwest passage. London: Penguin.

Woodman, D.C. 1991. Unravelling the Franklin mystery: Inuit testimony. Montreal: McGill-Queen's University Press.

Woodman, D.C. 1995. Strangers among us. Montreal: McGillQueen's University Press.

Woods, R. 2000. The demography of Victorian England and Wales. Cambridge: Cambridge University Press.

Woods, R. and N. Shelton. 1997. An atlas of Victorian mortality. Liverpool: Liverpool University Press. 